\title{
An Aquatic Pathways Model to Predict the Fate of Phenolic Compounds
}
R. L. Aaberg
R. A. Peloquin
D. L. Strenge
P. L. Mellinger

April 1983

Prepared for the U.S. Department of Energy under Contract DE-AC06-76RLO 1830

Pacific Northwest Laboratory Operated for the U.S. Department of Energy by Battelle Memorial Institute 


\title{
DISCLAIMER
}

This report was prepared as an account of work sponsored by an agency of the United States Government. Neither the United States Government nor any agency thereof, nor any of their employees, makes any warranty, express or implied, or assumes any legal liability or responsibility for the accuracy, completeness, or usefulness of any information, apparatus, product, or process disclosed, or represents that its use would not infringe privately owned rights. Reference herein to any specific commercial product, process, or service by trade name, trademark, manufacturer, or otherwise, does not necessarily constitute or imply its endorsement, recommendation, or favoring by the United States Government or any agency thereof. The views and opinions of authors expressed herein do not necessarily state or reflect those of the United States Government or any agency thereof.

\author{
PACIFIC NORTHWEST LABORATORY \\ operated by \\ BATTELLE \\ for the \\ UNITED STATES DEPARTMENT OF ENERGY \\ under Contract DE-AC06-76RLO 1830
}

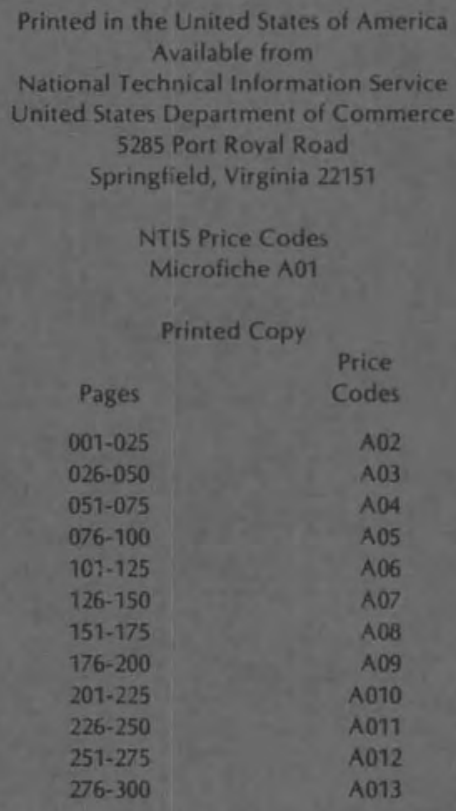


PNL -4202

UC-90d

AN AQUATIC PATHWAYS MODEL TO PREDICT THE FATE OF PHENOLIC COMPOUNDS

R. L. Aaberg

R. A. Peloquin

D. L. Strenge

P. J. Mellinger

April 1983

Prepared for the U.S. Department or Energy under Contract DE-AC06-76RLO 1830

Pacific Northwest Laboratory

Richland, Washington 99352 
PREFACE

This report describes a model that can he used to estimate the potential environmental transport, fate, and resulting concentrations of organic materials available to humans from releases of complex organic fuels to the aquatic environment. A detailed description and a user's guide for the Aquatic Pathways Model are given in the Appendixes in a separate volume (PNL-4202, APP A-D).

This effort is part of the Ecological Effects of Coal Conversion project managed by Duane H. Fickeisen of Pacific Northwest Laboratory (PNL). The overall program is managed by Dr. F. J. Wobber of the Department of Energy, Office of Health and Environmental Research, Office of Ecological Research. Experimental data being developed at PNL and scientific judgments will continue to be incorporated into the model as they are obtained, and results will be compared through a sensitivity analysis. The effort will be aimed at prioritizing research needs and coordinating efforts of environmental chemistry and aquatic and terrestrial biology tasks.

The primary purpose of the model is to be a screening and predictive tool for exposure to man via the aquatic pathway. In addition, the framework of this model may be used with other chemicals and different physical situations for which exchange rates between compartments are known. 
$\checkmark$ 


\section{ACKNOWLEDGMENTS}

The principal author would like to thank all the individuals involved in this project. The contributors to this document include R. A. Peloquin, who programmed and implemented the model; D. L. Strenge, who reviewed models and provided technical assistance; and P. J. Mellinger, Project Manager, who gave encouragement and guidance. I would also like to thank the other members of the SRC team who reviewed the document, and Carolynn Novich who edited the report. Special thanks goes to Carolyn Schauls, who typed and revised this report throughout its development, and the freelance word processing team, who typed the final version. 
Organic materials released from energy-related activities could affect human health and the environment. To better assess possible impacts, we developed a model to predict the fate of spills or discharges of pollutants into flowing or static bodies of fresh water.

A computer code, Aquatic Pathways Model (APM), was written to implement the model. The computer programs use compartmental analysis to simulate aquatic ecosystems. The APM estimates the concentrations of chemicals in fish tissue, water and sediment, and is therefore useful for assessing exposure to humans through aquatic pathways.

The APM will consider any aquatic pathway for which the user has transport data. Additionally, APM will estimate transport rates from physical and chemical properties of chemicals between several key compartments. The major pathways considered are biodegradation, fish and sediment uptake, photolysis, and evaporation. The model has been implemented with parameters for distribution of phenols, an important class of compounds found in the water-soluble fractions of coal liquids.

In areas where additional information is required for the model to more accurately predict the fate of aqueous releases of complex organic mixtures, experiments have been suggested. The model was developed to estimate the fate of liquids derived from coal, but it could be applied to other chemical contaminants as well.

The structure of the model allows a great deal of flexibility in its application. The major restriction of the current model is the use of first order rate constants, which describe the exchange of material between compartments. The material exchanged could be any material for which transfer coefficients are known. The compartments could be any set of components of an aquatic ecosystem.

Validation of APM is needed to confirm or improve its capacity as a predictive tool. In addition, the data used to derive model parameters should be revised as more information becomes available. 
Current modeling efforts show that, in comparison with many pesticides and polyaromatic hydrocarbons (PAH), the lighter phenolics (the cresols) are not persistent in the environment. The properties of heavier molecular weight phenolics (indanols, naphthols) are not well enough understood at this time to make similar judgments. For the twelve phenolics studied, biodegradation appears to be the major pathway for elimination from aquatic environments. A pond system simulation (using APM) of a spill of solvent refines coal (SRC-II) materials indicates that phenol, cresols, and other single cyclic phenolics are degraded to 16 to 25 percent of their original concentrations within 30 hours. Adsorption of these compounds into sediments and accumulation by fish was minor.

Results of a simulated spill of a coal liquid (SRC-II) into a pond show that APM predicted the allocation of 12 phenolic components among six compartments at 30 hours after a small spill.

The simulation indicated that most of the introduced phenolic compounds were biodegraded. No degradation was assumed for C5 phenol and the indanols, where insufficient information was available. Photolysis was estimated to be a minor degradation pathway for all pheolic compounds except resorcinol.

The phenolics remaining in the aquatic system partitioned according to their molecular weight and structure. A substantial amount was predicted to remain in the water, with less than $0.01 \%$ distributed in sediment or fish. 


\section{CONTENTS}

PREFACE $\ldots \ldots \ldots \ldots \ldots \ldots \ldots \ldots \ldots \ldots \ldots \ldots \ldots \ldots \ldots \ldots \ldots \ldots \ldots \ldots \ldots \ldots \ldots \ldots \ldots$ ACKNOWLEDGMENTS $\ldots \ldots \ldots \ldots \ldots \ldots \ldots \ldots \ldots \ldots \ldots \ldots \ldots \ldots \ldots \ldots \ldots \ldots \ldots \ldots \ldots$

SUMMARY $\ldots \ldots \ldots \ldots \ldots \ldots \ldots \ldots \ldots \ldots \ldots \ldots \ldots \ldots \ldots \ldots \ldots \ldots \ldots \ldots \ldots \ldots \ldots \ldots \ldots$

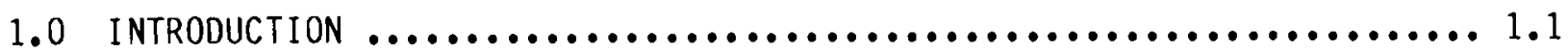

1.1 MODELS REVIEWED $\ldots \ldots \ldots \ldots \ldots \ldots \ldots \ldots \ldots \ldots \ldots \ldots \ldots \ldots \ldots \ldots \ldots \ldots \ldots$

1.2 THE AquATIC PATHWAYS MODEL $\ldots \ldots \ldots \ldots \ldots \ldots \ldots \ldots \ldots \ldots \ldots \ldots \ldots \ldots \ldots \ldots \ldots \ldots \ldots$

2.0 JUSTIFICATION OF COMPARTMENTAL DATA SELECTION $\ldots \ldots \ldots \ldots \ldots \ldots \ldots \ldots \ldots \ldots$

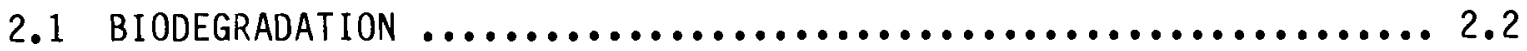

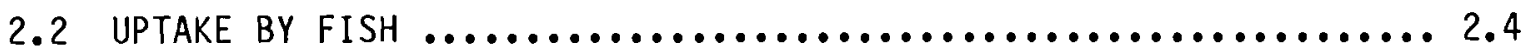

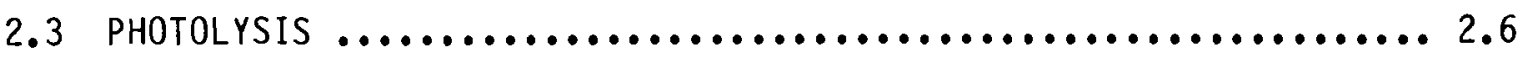

2.4 ADSORPTION ONTO SEDIMENTS $\ldots \ldots \ldots \ldots \ldots \ldots \ldots \ldots \ldots \ldots \ldots \ldots \ldots \ldots \ldots \ldots$

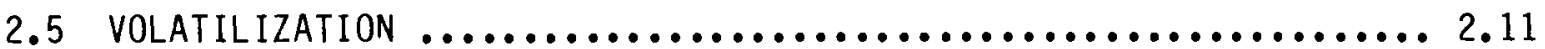

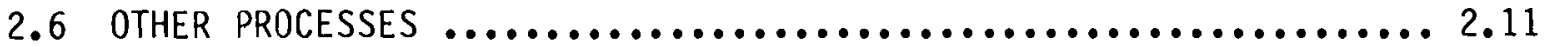

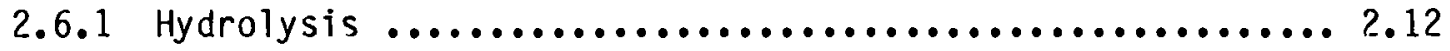

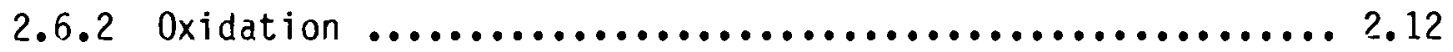

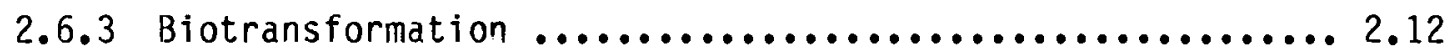

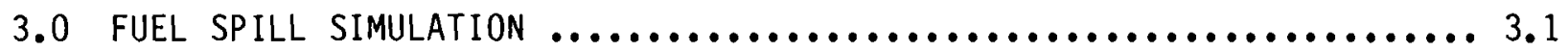

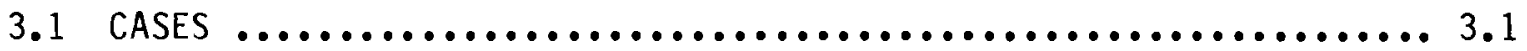

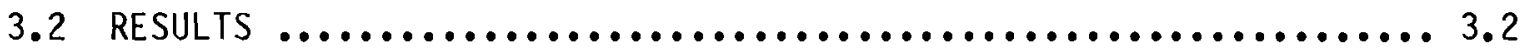

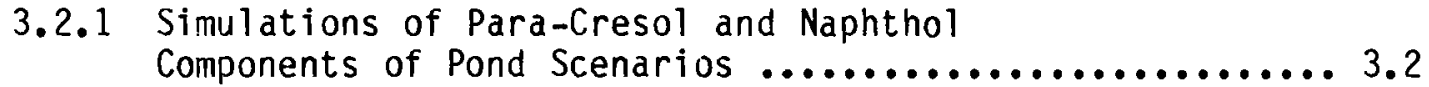

3.2.2 Simulation of Para-Cresol in a River Scenario .......... 3.7

4.0 ANILINES AND HETEROCYCLIC COMPOUNDS $\ldots \ldots \ldots \ldots \ldots \ldots \ldots \ldots \ldots \ldots \ldots \ldots \ldots$

5.0 CONCLUSIONS AND RECOMMENDATIONS $\ldots \ldots \ldots \ldots \ldots \ldots \ldots \ldots \ldots \ldots \ldots \ldots \ldots \ldots \ldots \ldots$

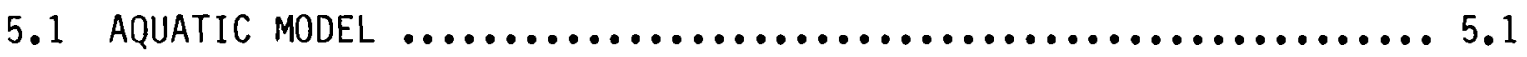


5.2 DATA BASE DEVELOPMENT $\ldots \ldots \ldots \ldots \ldots \ldots \ldots \ldots \ldots \ldots \ldots \ldots \ldots \ldots \ldots \ldots \ldots \ldots \ldots \ldots \ldots \ldots \ldots \ldots$

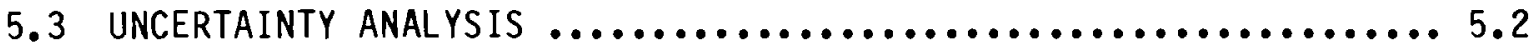

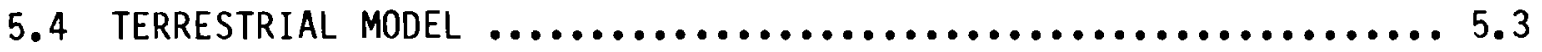

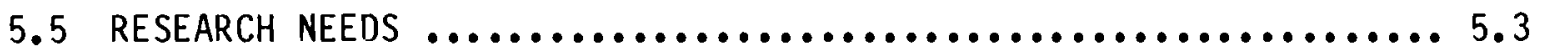

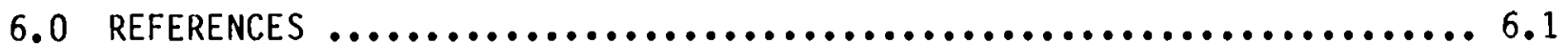

APPENDIXES (under separate cover, PNL-4202, APP A-D)

APPENDIX A - AQUATIC ECOSYSTEM TRANSPORT MODELS ............... A. 1

APPENDIX B - AQUATIC PATHWAYS MODEL SYSTEM AND MODEL .............. DESCRIPTION

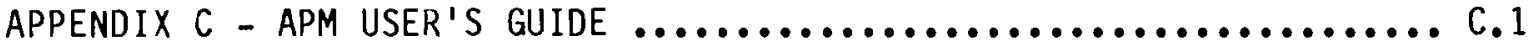

APPENDIX D - DATA BASE AND CODE LISTINGS $\ldots \ldots \ldots \ldots \ldots \ldots \ldots \ldots \ldots \ldots$. . 1 


\section{FIGURES}

1.1 A Typical Aquatic Exposure Pathways Diagram .................... 1..2

1.2 Pathways Diagram of the APM Computer Program ................... 1.9

2.1 Oxidation of Hydroxyphenols and Methylphenols ..................2.2

3.1 Fate of Para-Cresol in a 30-Hour Pond Simulation ................ 3.4

3.2 Concentration of Para-Cresol in Fish from Pond Simulation ......... 3.5

3.3 Fate of Naphthol in a 30 -Hour Pond Simulation ................... 3.6

3.4 Fate of Para-Cresol Component of a 10,000-L SRC-II Spill ..........3.8 into a Pond

4.1 Structure of Aniline and Representative Nitrogen- ............... 4.1 Containing Heterocyclic Compounds

\section{TABLES}

1.1 Phenols in Aqueous Suspensions of Solvent Refined Coal ........... 1.4

2.1 Relative Molar Extinction Coefficients for Absorption ............ 2.8 Spectra of Cresols in $0.01 \mathrm{Molar} \mathrm{KOH}$

3.1 Distribution of Phenolic Compounds 30 Hours after ...................3 Simulated SRC-II Spill into a Pond

3.2 Fate of Para-Cresol in a 30-Hour Pond Simulation ...................3

3.3 Fate of Naphthol in a 30-Hour Pond Simulation ...................... 3.

3.4 Simulation of Para-Cresol Component of a 10,000-L SRC-II ........... 3.7 Spill into a Pond

3.5 Simulation of Para-Cresol Component of SRC-II in a River .......... 3.9 $20 \mathrm{Hr}$ After a Spill

3.6 Simulation of Para-Cresol Component of SRC-II in a River .......... 3.9 $100 \mathrm{Hr}$ After a Spill 


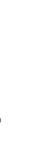


AN AQUATIC PATHWAYS MODEL TO PREDICT

THE FATE OF PHENOLIC COMPOUNDS

\subsection{INTRODUCTION}

The Aquatic Pathways Model (APM) is a mathematical representation of the distribution of organic materials among components of an aquatic ecosystem. The model is designed to simultaneously describe the time-dependent distribution of several compounds and, thus, may be applied to screening and estimating the fate of compounds contained in complex mixtures. It has broad application to many compounds and to many aquatic ecosystems, including both flowing (lentic) and non-flowing (lotic) systems.

Although predictive models are generally limited because they use simplified assumptions and approximations of real situations, they can be used to determine order-of-magnitude variations in estimated quantities. As such, models can be used to guide environmental research by highlighting potential exposure pathways and mechanisms that are either very significant or of no consequence. A typical aquatic exposure pathways diagram is given in Figure 1.1. Compartments are represented by boxes, and transfers between compartments are indicated by arrows.

Because of our research interest in the environmental fate of synthetic fuels derived from coal, the model was implemented for a spill of a coal liquid and includes a module to simulate the proportions of phenolic compounds entering the water-phase from a spill of solvent refined coal (SRC-II) material. With changes in the parameters, however, the model could be applied to other synthetic or petroleum products.

Phenolic compounds were chosen as the first class of chemicals to be investigated by APM because they are more readily water soluble than other aromatics and hydrocarbons, they make up a large part of the water soluble fraction (WSF) of coal liquids, and they are highly toxic. The solubility of phenol in water is $93 \mathrm{~g} / \mathrm{L}$, versus, for example, $0.7 \mathrm{~g} / \mathrm{L}$ for benzene; thus, phenolics will be dispersed rapidly if a spill occurs and are liable to affect 


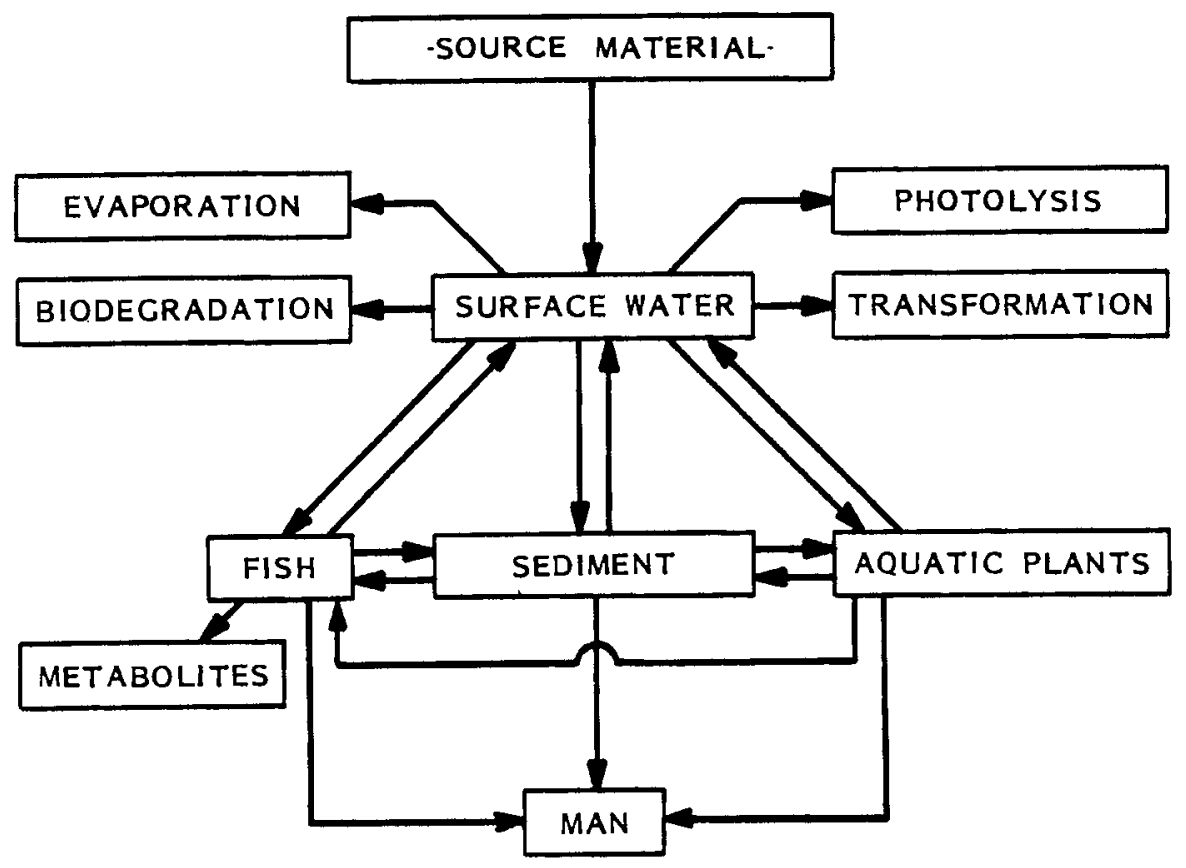

FIGURE 1.1. A Typical Aquatic Exposure Pathways Diagram

an area larger than the slick itself. Even if undissolved oil is recovered, aquatic organisms will be exposed to dissolved phenols.

Phenols predominate in the initial WSF of solutions of coal liquids. For example, in an aqueous solution of SRC-II liquid (2.9:1 middle to heavy distillate) phenols constituted $76 \%$ of the total organic carbon (Strand and Vaughan 1981). Initial aqueous solutions containing $1 \%$ SRC-II blend (2.9:1) contained about $1100 \mathrm{mg} / \mathrm{L}$ phenols and $17 \mathrm{mg} / \mathrm{L}$ PAH. Proposed coal-derived liquid materials from the SRC-II process contain more phenols, aromatic compounds, and heterocyclic compounds than do petroleum-based fuels (Dooley et al. 1978). SRC-II material contains a larger proportion of water soluble constituents than does crude oil or petroleum fuel oils. For example, similarly prepared WSFs of SRC-II blend contained 1000 to $1100 \mathrm{mg} / \mathrm{L}$ total carbon, compared to 4 to $9 \mathrm{mg} / \mathrm{L}$ for fuel oils (Strand and Vaughan 1981).

Phenolics are acutely toxic to aquatic life in the $\mathrm{mg} / \mathrm{L}$ range. The 96-hour median lethal concentration (LC50) for phenol for a variety of fish ranges from 11 to $44 \mathrm{mg} / \mathrm{L}$ (Buikema, McGinniss and Cairns 1979); for cresols the 
range is about 10 to $24 \mathrm{mg} / \mathrm{L}$. Based on dilutions of WSF, the toxicity of SRC liquid materials to aquatic life is much greater than that of conventional petroleum fuels.

Many models described in the literature were designed to assess environmental consequences resulting from introduction of a foreign substance. From these models, individual submodels were selected for use in the Aquatic Pathways Model (APM). The APM has two main advantages over most other models: it requires simple input information, which is more apt to be available than complex information; and the use of such simple informations allows the program to be run on a microcomputer, which makes the code portable and inexpensive to run. Since the APM code was first developed, the capabilities of microcomputers have increased greatly. Larger programs fit more easily on inexpensive microcomputers, making these programs more readily adaptable. The APM and its matrix method of calculation provide a straight-forward and relatively fast solution to first order differential equations that form its base.

A literature search for applicable on data phenolic compounds was conducted concurrently with model development. Toxicity of chemical species was not addressed in the model. In future modifications, toxicity data could be included and compared with predicted concentrations.

Twelve phenolic compounds, all considered in this evaluation, have been identified in aqueous suspensions of SRC-II blends (Strand and Vaughan 1981). The approximate amount of each chemical forming the water soluble fraction was estimated from data on 2.9:1 middle to heavy distillate blend. The composition of the phenolic components of the WSF of SRC-II blend, which are used as input to the computer code, are listed in Table 1.1.

\subsection{MODELS REVIEWED}

Models for assessing the environmental concentrations of chemicals released to aquatic ecosystems were reviewed to determine their applicability for use in the APM. The review considered the type of compounds, the characteristics of ecosystems for which the model was developed, and the problems 
TABLE 1.1. Phenols in Aqueous Suspensions of Solvent Refined Coal

\begin{tabular}{lcc}
\multicolumn{1}{c}{ Chemical Compound } & $\begin{array}{c}\text { Concentration, (a) } \\
\mathrm{mg} / \mathrm{L}\end{array}$ & \multicolumn{2}{c}{$\begin{array}{c}\text { Input to Water } \\
\mathrm{g} / \mathrm{L} \text { SRC-I I Blend }\end{array}$} \\
Phenol & 169 & 16.9 \\
Methyl phenols (cresols) & & 8.1 \\
ortho-cresol & 169 & 16.9 \\
para-cresol & 124 & 12.4 \\
meta-cresol & 292 & 29.2 \\
C-2 Phenols & 96 & 9.6 \\
C-3 Phenols & 33 & 3.3 \\
C-4 Phenols & 3 & 0.3 \\
C-5 Phenols & -- & 0.7 (b) \\
Resorcinols & & \\
Indanols & 53 & 5.3 \\
C-1 Indanols & 29 & 2.9 \\
C-2 Indanols & -- & $0.4(\mathrm{~b})$ \\
Naphthols & 1059 & 106 \\
Total phenols & &
\end{tabular}

(a) Based on aqueous solution containing $300 \mathrm{~mL}$ SRC-II blend plus 29.7 L water.

(b) $1.1 \mathrm{~g} / \mathrm{L}$ "other" from Strand and Vaughan (1981) is assumed to be $0.7 \mathrm{~g} / \mathrm{L}$ resorcinols and $0.4 \mathrm{~g} / \mathrm{L}$ naphthols.

that could occur when extending the model for use with phenols. A brief summary of each model reviewed is given below. A detailed description of selected models is provided in Appendix A.

The Neely Fish Pond Model (Neely 1979a) is a dynamic model developed to predict concentrations of neutral (non-polar) organic chemicals in a simple aquatic ecosystem. The model (PEEC) uses theoretical and empirical equations to estimate transfer rate constants between compartments.

The Hicks Matrix Model (Hicks 1981) describes a general matrix modeling technique for a system of compartments with various transfer mechanisms between 
compartments. Two methods of solving the differential equations are described: Euler's method and a Runge-Kutta method.

The Sandia FOODWEB Model (Niemczyk 1980) was developed to represent dynamic trnnsport of radionuclides in fresh waters and shallow marine ecosystems. The model is a compartment model similar to the above two models, but it has a more detailed definition of system components.

The Onishi Transport Models (Onishi and Trent 1981) are two- and threedimensional models that estimate radionuclide transport in rivers, coastal waters, and estuaries. The models include radionuclide-sediment interactions plus sediment movement, which controls transport, deposition, and resuspension of sorbed radionuclides. Because the computer programs for implementing the models are quite complex, it is difficult to use the models in our program. For systems involving significant water movement or wave action, however, some method should be considered to describe transport.

The Mackay-Paterson Fate Model (Mackay and Paterson 1981) estimates the ultimate fate of chemicals in the environment. The model is strictly based on equilibrium partitioning between the major environmental compartments and is designed to indicate relative amounts of substances that will partition into each compartment, including the relative concentration of each substance in the compartment.

The Exposure Analysis Modeling System (EXAMS) (Burns, Cline and Lassiter 1982), developed by the Environmental Protection Agency (EPA), estimates behavior of chemical pollutants in natural aquatic systems. EXAMS is a multicompartment model that evaluates volatilization, transport, direct photolysis, hydrolysis, oxidation, and bacterial transformations in the water column and bottom sediments.

The Nuclear Regulatory Commission (NRC) PATH1 model (Helton and Kaestner 1981) is a multi-compartment model designed to estimate radionuclide transport in the environment and to humans. The computer program is general and could be used to describe a variety of environments (i.e., combination of lakes, rivers and reservoirs) if the input parameters are appropriately defined. 
The Fate of Aromatics Model (FOAM) (Bartell et al. 1981) predicts the transport and fate of polycyclic aromatic hydrocarbons (PAH). The fate of PAH is pedicted from basic chemical properties of PAH. Fate pathways predicted include volatilization, photolysis, sorption to sediments and particulates, and net accumulation by biota.

The Simplified Lake or Stream Model (SLSA) was developed by DiToro et al. (1981) for the Chemical Manufacturers' Association to study the fate of chemicals in lakes and streams. The model is similar to other compartment models and associates pollutants with suspended and particulate solids in a water medium.

\subsection{THE AQUATIC PATHWAYS MODEL}

The APM is a collection of computer codes. A detailed description of the codes is given and their finite interactions are discussed in Appendix B, System and Model Description which is located in PNL-4202, APP A-D.

The model is based on a system of linear first order differential equations. A linear compartment model was used because of its simplicity and straightforward application, and because many systems behave more or less linearly, especially for response to relatively small perturbations (Blau, Neely and Branson 1975). Linear compartment models, however, must be used with caution because some process (e.g., saturation) exhibit non-linear behavior.

Computer codes described in this section were developed to model the spill of coal liquids into either a static or flowing body of water. APM predicts partitioning between various compartments selected by the user. The results provide a screening-level assessment of the fate of spilled materials, or, with slight modification, of chronic releases on aquatic systems. This type of capability could be used for planning or for emergency response situations.

The simulation is divided into two programs. The first program calculates the amount of each compound in a postulated SRC-II material spill of a given size. This program generates input files for each compound used in the second program, which simulate behavior in the aquatic environment selected. 
The computer code for the first phase is named Aquatic Pathways Model of a Coal Liquid Spill (APMSPILL). APMSPILL is a separate program which functions as a superstructure to Aquatic Pathways Model of Toxic Chemicals (APM). This partitioning of the code allows greater flexibility in code usage. The major section of the code package (APM) is less specific, and its application is not limited to coal liquids.

APMSPILL prints a report of the amount of selected compounds that would be present in a coal liquid spill of a given size. The compounds currently considered by APMSPILL are phenol, o-cresol, p-cresol, m-cresol, C2-phenol, C3-phenol, C4-phenol, C5-phenol, 5-indanol, C1-indanol, resorcinol, and naphthol. A file for each of these compounds is created by APMSPILL for the particular environment specified by the user. This file is the input to the APM code.

APM simulates the fate of a compound in a static or flowing body of water. The aquatic ecosystem is partitioned into user-selected compartments, which are assumed to have uniform transport and transformation characteristics. Instantaneous mixing of the chemical is assumed for all compartments. Partitioning of the chemical into the various compartments is followed for a given time period.

Users may select any combination of the following compartments to represent the system: water, sediment, fish, evaporation, hydrolysis, biodegradation, and photolysis. Additional compartments can be added without modifying the code, because all such specific parameters are stored in data bases separate from the code. The user selects the size of each compartment in the system. The system is "closed" in that some of the compartments serve only as sinks to chart the amount of compound leaving the system through various processes (e.g., hydrolysis).

The system to be modeled can be either static (pond or lake) or flowing (river). Minor modifications to the code would allow simulating a pond or lake with streams flowing in or out of the system. The river model is constructed as a number of user-selected lengths, referred to as "reaches." Compound flowing out of each reach during each time period is input into the next reach 
during the corresponding time period. This allows the user to keep track of the compounds as they flow downstream.

APM can simulate a range of time periods, depending on the size of time steps selected and the number of iterations between time steps. The size of the step appropriate for a given simulation is related to the time constant of a flowing system and rate constants of compounds selected. Simulations on the order of days have been run.

The code stores data for each one-hundredth of the total time period for output and graphing. The user controls precision and execution speed by specifying how many iterations will take place in each of the one-hundred time periods, and the length of each time period (in hours). Currently, the user must determine the appropriateness of the total number of iterations for a given simulation. This can be done by increasing the number of iterations in a test case to determine the degree of accuracy lost in a quicker simulation. Later enhancements to the code could include testing interrelations between parameters.

A conceptual model of the current version of APM is depicted in Figure 1.2. Each compartment of the system is represented by a box with a number $(Q N)$. Flow of compound between the compartments is signified by arrows with numbers $(\mathrm{Km}, \mathrm{n})$ that show the direction of flow. The first number indicates which compartment is the receiver; the second indicates which is the source. The computer code allows for transfer of compounds between any of the compartments in the system. The code will automatically consider flow between compartments which are selected for a case and between which there is a rate constant.

A mass balance is performed on each compartment for each time step. The simulation is accomplished mathematically by a system of differential equations. Differential equations which are used to define the system as conceptualized in Figure 1.2 are as follows:

$$
d Q x / d t=(K x y \star Q y)-(K y x \star Q x)
$$




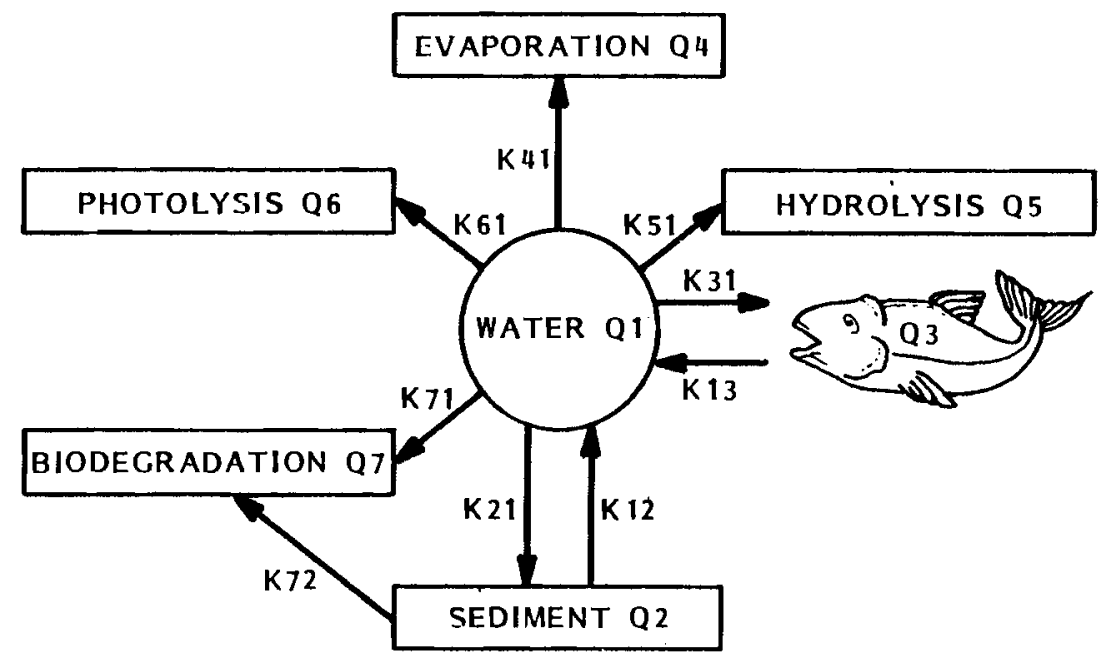

FIGURE 1.2. Pathways Diagram of the APM Computer Program

where $Q x$ is the quantity of material in a compartment of the system as defined in Figure 1.2, and $K x y$ is the rate of transfer of material from compartment $y$ to compartment $x$ as defined in Figure 1.2 .

The mass balance on the water compartment includes terms for interaction with sediment and fish, and removal or sink terms for evaporation, hydrolysis, and photolysis. The differential equation describing the water compartment is as follows:

$$
\begin{aligned}
\mathrm{dQ} 1 / \mathrm{dT}= & (K 13 * \mathrm{Q} 3)+(K 12 * \mathrm{Q} 2)-(\mathrm{K} 21 * \mathrm{Q} 1)-(\mathrm{K} 71 * \mathrm{Q} 1)-(\mathrm{K} 61 * \mathrm{Q} 1) \\
& -(K 41 * \mathrm{Q} 1)-(K 51 * \mathrm{Q} 1)-(K 31 * \mathrm{Q} 1)
\end{aligned}
$$

Adsorption removes the chemical from the water and binds it to the sediment. Materials bound to sediment may be released back to the water depending on sediment-water equilibria. Degradation of material by bacteria is a removal term for this compartment.

A mass balance on the sediment compartment yields the following differential equation:

$$
\mathrm{dQ} 2 / \mathrm{dt}=(\mathrm{K} 21 * \mathrm{Q} 1)-(\mathrm{K} 12 * \mathrm{Q} 2)-(\mathrm{K} 72 * \mathrm{Q} 2)
$$


Fish can accumulate chemicals from their water environment. Two terms, an uptake term and a depuration term, are used to describe this process.

A mass balance on the fish compartment yields the following differential equation:

$$
\mathrm{dQ} 3 / \mathrm{dt}=(\mathrm{K} 31 * \mathrm{Q} 1)-(\mathrm{K} 13 * \mathrm{Q} 3)
$$

Evaporation or volatilization is a removal term for chemicals in the APM. The mass balance for this pathway is as follows:

$$
\mathrm{dQ} 4 / \mathrm{dt}=\mathrm{K} 41 * \mathrm{Q} 1
$$

Hydrolysis is a chemical reaction in which a compound reacts with the ions of water $\left(\mathrm{H}^{+}\right.$or $\left.\mathrm{OH}^{-}\right)$. The mass balance for this reaction pathway is as follows:

$$
\mathrm{dQ} 5 / \mathrm{dt}=\mathrm{K} 51 * Q 1
$$

Photolysis is a chemical transformation initiated by absorption of radiant energy. Like evaporation and hydrolysis, photolysis is a removal term for materials in the APM. A mass balance on the photolysis compartment yields the following differential equation:

$$
\mathrm{dQ6} / \mathrm{dt}=\mathrm{K} 61 * Q 1
$$

Biodegradation is the breaking down or metabolism of chemical compounds by living organisms. Bacterial degradation is a removal term for materials in water and in sediment compartments.

The differential equation describing the biodegradation compartment is as follows:

$$
\mathrm{dQ7} / \mathrm{dt}=(\mathrm{K} 72 * \mathrm{Q} 2)+(\mathrm{K} 71 * \mathrm{Q} 1)
$$


The Runge-Kutta evaluation method was chosen to solve the system of linear differential equations. The fourth-order Runge-Kutta method (Gill 1951) was used in an attempt to reduce numerical errors in the solution. The error associated with the Runge-Kutta method is proportional to the fourth power of the time step, which is much smaller than the error associated with the EulerCauchy method, used in earlier versions of the code.

The program is generally not limited by numerical solution when time steps and compartment sizes are well chosen. The quality and applicability of data and assumptions about the system are more likely to be limiting. Correlations used to predict uptake by fish and sediment are, at best, order-of-magnitude estimates. Assumptions of instantaneous mixing in the water compartments in both pond and river systems are more limiting than are numerical errors. 


\subsection{JUSTIFICATION OF COMPARTMENTAL DATA SELECTION}

The APM requires a minimum data base of water solubility, vapor pressure, and molecular weight of the chemical. These few readily available data allow estimation of rate constants that characterize movement of chemicals from water to soil, air, and fish. The PEEC computer program, on which the APM is based, was originally written to assess the maximum environmental concentration of a neutral (non-polar) organic chemical substance in a simple ecosystem (Neely 1979a). Compounds of higher water solubility, such as simple phenolic compounds, are on the limits of the range of applicability.

Rate constants for hydrolysis, phytolysis, biodegradation, and fish metabolism are not calculated by regression equations and must be determined experimentally. With sufficient data, some of the transformations may be predicted using molecular properties; for example, metabolism by fish (hydroxylation, conjugation) can be correlated with the Hammett constant (Lu and Metcalf 1975). We have used data from the literature in our work, and will incorporate new data, as they become available, into later iterations.

The octanol-water partition coefficient (Kow) is used extensively in rate constant correlations. Values of the Kow compiled by Leo, Hansch and Elkins (1971) were usually more accessible than solubility data. Estimates of Kows for substituted phenols, using corrections for substituent groups, were made when necessary. Estimates of the Kows of indanols were made based on cyclohexane-water partition coefficients and their correlations with Kows (Leo, Hansch and Elkins 1971). Kow may also be estimated from solubility data, when available (Chiou et al. 1971).

Smith et al. (1978) experimentally determined rates of volatilization, photolysis, oxidation, hydrolysis, biodegradation, and sorption for nine compounds that were expected to be found in fossil fuels. These data have been used in this study as a basis for other rate constants. 


\subsection{BIODEGRADATION}

Simulations and a review of literature indicate that biodegradation is the most important loss mechanism for phenols in aquatic environments (Buikema, McGinniss and Cairns 1979). Therefore, where rate data do not exist, biodegradation rate constants must be estimated based on degradation experiments from the literature. Many assumptions are made to estimate these first order rate constants. In reality, bacterial population size and dissolved oxygen are important and could be addressed in future iterations.

Because there is a direct relationship between rates of oxygen uptake and disappearance of substrate, slopes of oxygen uptake curves could be used to estimate degradation rates. Rate constants for biodegradation of various phenols were estimated for this study based on para-cresol (or p-cresol, a methyl phenol) data and other data from Chambers, Tabak and Kabler (1963) as illustrated in Figure 2.1.

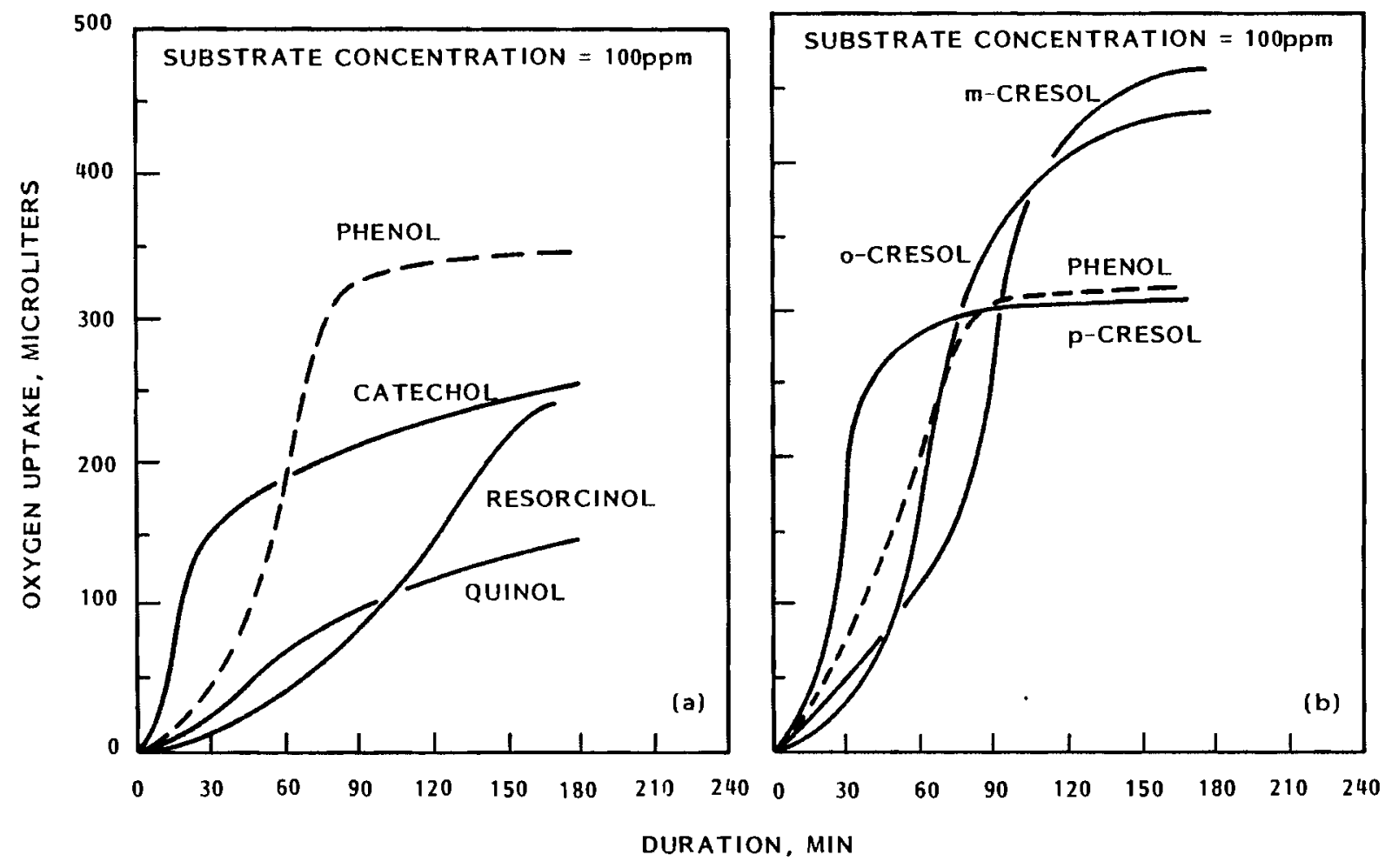

FIGURE 2.1. Oxidation of Hydroxyphenols (a) and Methylphenols (b) 
The rate of biodegradation increases as the number of active bacterial cells in the body of water increases. Smith et al. (1978) generated biodegradation rate constants based on an active bacteria concentration of 100,000 cells/mL for simulations of pond, river, and eutrophic lake systems. No temperature dependence has been incorporated at this stage.

Known biodegradation rate constants from Smith and the oxygen untake curve for para-cresol from Chambers, Tabak and Kabler (1963) allow rate constants from oxygen uptake curves to be estimated for other chemicals. Because the curves are not linear, maximum slopes were used in APM calculations. Curves in Figure 2.1 suggest that different compounds may have different final values of oxygen uptake. This may be due to the degree of oxidation of the compound by bacteria (i.e., inability to oxidize some compounds to completion) and/or stoichiometry of the reactions. Of these two conditions, incomplete oxidation is assumed to be more important. These factors should not affect order-ofmagnitude estimates of degradation rates.

Using short-term tests with enriched cultures of bacteria to estimate long-term activity in the environment may produce rate constants of limited validity. However, qualitative assumptions on biodegradability of simple versus highly substituted compounds are reasonable.

Data on oxygen uptake rates from bacterial metabolism of aromatic hydrocarbons (Gibson 1972) were used to estimate effects of alkyl substituents on degradation of phenolic compounds. Degradation is slower as the weight and complexity of substituted groups increase (Buikema, McGinniss and Cairns 1979). Dihydric and trihydric phenols, such as resorcinol, are also resistant to degradation. The actual ability of an organism to metabolize specific alkylphenols is dependent on the phenol structure and on the specificity of enzymes used by the organism (Chapman 1972).

Little information is available on the degradation of multicyclic phenols. A degradation rate constant for naphthols is based on degradation of 1-naphthol in sea water (Lamberton and Claeys 1970). No data on degradation of indanols was found. Indanols are assumed to be more resistant to degradation than 
simple phenolics because they possess a five-member ring, which may be viewed as a complex constituent group, and makes these compounds more difficult to metabolize.

\subsection{UPTAKE BY FISH}

Uptake of chemicals by fish has been shown to correlate well with octanolwater partition coefficients (Neely, Branson and Blau 1974; Veith et al. 1980; Kenega and Goring 1980). Representative regression equations used to predict the bioconcentration factor (BCF) from the octanol-water partition coefficient are given below:

$$
\begin{aligned}
& \log B C F=0.542 \log \text { Kow }+0.24 \\
& \log B C F=0.85 \log \text { Kow }-0.70 \\
& \log B C F=0.75 \log \text { Kow }-0.23
\end{aligned}
$$

Equation 2.1 (Neely, Branson and Blau 1974) was developed for concentration of eight organic, nonpolar compounds in rainbow trout muscle. Fquation 2.2 was derived for 59 chemical compounds with a range of partition coefficients of over six orders-of-magnitude from experiments with fathead minnow, rainbow trout, and bluegill (Veith, Defoe and Bergstedt 1979). Equation 2.3 was generated from tests of 84 compounds conducted by several researchers (Veith et al. 1980).

Estimates of BCF have a greater uncertainty for compounds of relatively high water solubility. This is not a serious limitation because the BCFs for these compounds are less important than BCFs for highly bioaccumulative compounds (Veith et a1. 1980). Equations 2.1 through 2.3 predict BCFs of between four and eight for phenol in fish. PNL data for phenol suggest a BCF of between 5 and 30 in Scenedesmus (algae) (PNL 1982). Values of BCFs from the literature for fish exposed to phenol range from about one to three (Kobayashi and Akitake 1975; Swift 1978) to 15,800 (Call, Brooke and Lu 1980). Differences in experimental methods may explain these discrepancies. Kobayashi and Akitake (1975) and Swift (1978) used colorimetric methods of determining phenol concentration. Call, Brooke and Lu (1980) used carbon-14 labeling. The 
carbon-14 counts were regarded as equivalent to parent compounds, when actually they could have been taken up in other forms (for example, as degradation products). This could result in an overestimate of the BCFs. Thus, use of the above regression equations for predicting BCF may be better than inappropriate experimental data; however, valid experimental data should be used in preference to the regression equations. Because Equation 2.3 is based on the largest number of compounds with low Kow, it should be used for estimating the BCF for pheonls. Hamelink and Spacie (1977) have suggested that predicting BCFs for an analogue series within a family of compounds would give more satisfactory results than methods based on partition coefficients alone. Perhaps such a relationship could be derived for phenols. The $B C F$ is used in rate calculations. It is an equilibrium concentration factor, which is the ratio of intake rate to depuration rate.

The rate constant of fish uptake of a chemical compound from water is calculated using the following equation from Neely (1979a):

$$
K 31=E / F 1 *(Q \star F 1 \sigma / E o x * \operatorname{Cox})
$$

where $\mathrm{K} 31$ = uptake rate of chemical by fish from water [mL chemical/

(g fish*hr)]

$E=$ efficiency of pollutant transfer across the gills. The following regression equation for data given by Neely (1979b) is used to calculate the transfer efficiency:

$$
E=0.07 \log \text { Kow }-0.02
$$

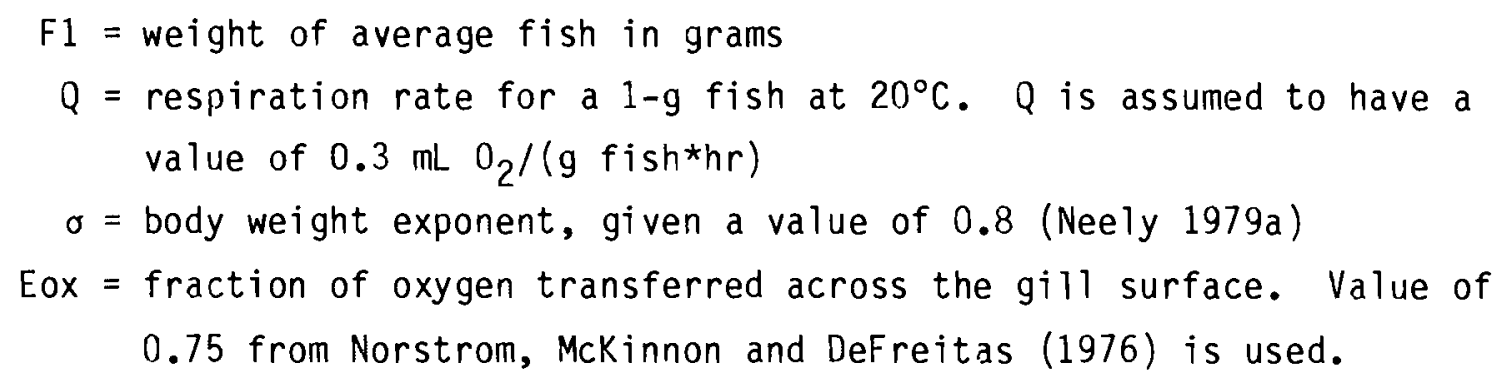




$$
\begin{aligned}
& \text { Cox }=\text { the concentration of oxygen in water }\left(\mathrm{mL} \mathrm{O}_{2} / 1\right. \text { iter at STP). } \\
& \text { Cox (in ppm) is calculated from temperature }\left(T \text {, in }{ }^{\circ} \mathrm{C}\right) \text { (Norstrom, } \\
& \text { Mckinnon and Defreitas 1976) and converted to proper units using } \\
& \text { the gas 1aw: } \\
& \qquad \begin{aligned}
\text { Cox }= & 14.45-(0.413 * T)+\left(0.00556 * \mathrm{~T}^{2}\right) \\
& (\text { in ppm or } \mathrm{mg} / \mathrm{L}) \\
\operatorname{Cox}(\mathrm{mL})= & \operatorname{Cox}(\mathrm{g}) \times 82 / 32 \times(T+273) .
\end{aligned}
\end{aligned}
$$$$
\text { Mckinnon and DeFreitas 1976) and converted to proper units using }
$$

At present, neither trans-cutaneous uptake nor foodweb uptake is considered. The depuration rate of the compound from the fish is also based on the Kow of that chemical and the rate of fish uptake of the compound (Neely 1979a):

$$
K 13=K 31 / B C F
$$

where $\mathrm{K} 13$ is the rate of transfer from fish to water ( $\mathrm{mL}$ water/g $\mathrm{fish}$ *hr), and $\mathrm{K} 31$ is the rate of transfer from water to fish ( $\mathrm{mL}$ water/g fish*hr).

Development of a two-compartment fish model may aid in modeling rapid initial uptake and depuration from fish, as indicated in experiments with phenol (Kobayashi and Akitake 1975.)

\subsection{PHOTOLYSIS}

Direct photolysis caused by the absorption of light is a chemical reaction that breaks molecular bonds and, hence, alters chemical species. Photolysis rate constants are dependent on a number of parameters such as absorption spectrum of the compound, intensity and wave lengths of impinging light, and quantum yield (fraction of the light absorbed which actually causes a reaction) for the transformation.

A detailed method for calculating direct photolysis rates of pollutants in aquatic environments was derived by Zepp and Cline (1977). In addition to chemical properties of the pollutant, their computer code calculates photolysis half lives as a function of season, latitude, time of day, depth and attenuation coefficients of water, and ozone layer thickness. 
The complete photolysis rate expression is shown in Equation 2.8 (Wolfe et al. 1976):

$$
-d(P) / d t=\phi \sum K_{a \lambda}(P)
$$

where $-d(P) / d t$ is the observed photolysis rate, $\phi$ is the quantum yield for reaction, and $\sum \mathrm{K}_{\mathrm{a} \lambda}$ is the sunlight absorption rate summed over all the wavelengths absorbed.

The photolysis half-life, $t_{1 / 2}$, is given by Equation 2.9:

$$
t_{1 / 2}=\ln 2 / \phi \sum K_{\mathrm{a} \lambda}
$$

An important determinant of direct photolysis rates is the ability of ultraviolet (UV) light to penetrate water. Absorption and scattering of UV light by materials in water also affect photolysis rates. Thus, water quality is a major factor in this mode of transformation. Intensity of solar UV light of short wavelength (297 to $320 \mathrm{~nm}$ ) is strongly influenced by solar zenith angle and atmospheric ozone content (Wolfe et al. 1976). The ozone layer absorbs wavelengths below approximately $290 \mathrm{~nm}$ (Crosby 1972). Longer wavelength UV light (330 to $390 \mathrm{~nm}$ ) is unaffected by ozone (Wolfe et al. 1976). Bond-breaking energies are generally in the shorter wavelength part of the natural light spectrum, 290 to $350 \mathrm{~nm}$ (Crosby 1972).

Absorption spectrum data are available in the chemical literature, and assumptions about location and season can be made. Quantum yield for reaction requires experinental data that are not readily available in the literature. The quantum yields of chemicals evaluated by Smith et al. (1978) range from $8 x$ $10^{-2}$ for para-cresol to $5 \times 10^{-4}$ for dibenzothiophene. Estimates of photolysis rates for simple phenols are made by taking ratios of molar extinction coefficients at different wave lengths and comparing them to those of para-cresol. For lack of better data, quantum yields are assumed to be similar.

The absorption spectra of para-, ortho- and meta-cresols in the UV energy range are compared in Table 2.1. Para-cresol absorbs more strongly than orthoor meta-cresols in the UV energy range. 
TABLE 2.1. Relative Molar Extinction Coefficjents
for Absorption Spectra of Cresols

in 0.01 Molar $\mathrm{KOH}$

\begin{tabular}{llll} 
Cresol: & \multicolumn{3}{c}{ Wavelength $(\mathrm{nm})$} \\
\cline { 2 - 5 } para-cresol & 1.0 & $\frac{310}{300}$ & $\frac{320}{1.0}$ \\
ortho-cresol & 0.60 & 0.17 & 1.0 \\
meta-cresol & 0.48 & 0.15 & 0.17
\end{tabular}

(a) Reference: Based on figures of $\log E$ (molar extinction coefficient) vs. wavelength (Lang 1961).

The relative photolysis rates of ortho- (0-cresol) and meta-cresol (m-cresol) are assumed to be one-third that of para-cresol. An estimate of the photolysis rate of naphthols is based on the degradation of 1-naphthol in sea water (Lamberton and Claeys 1970). The magnitude of light-induced decomposition is indicated by comparison of naphthol disappearance vs. time for light and dark conditions with sterile sea water as a medium. From data given for two experiments, the photolysis rates were estimated to be $2.5 \times 10^{-7} / \mathrm{sec}$ and 9 $x 10^{-8} / \mathrm{sec}$. This is within an order of magnitude of the photolysis rate of para-cresol $\left(6.8 \times 10^{-7} / \mathrm{sec}\right)$ determined by Smith et al. (1978). Photolys is rates of other phenolic compounds were not determined, but were assumed to be in this range.

There may be a variety of pathways for light-induced decomposition. The direct photolysis rate is a minimum estimate of photoreactivity (Wolfe et al. 1976).

\subsection{ADSORPTION ONTO SEDIMENTS}

The adsorption of materials onto sediments has been correlated with the organic carbon content of natural sediment and with water-octanol partitioning equilibria (Briggs 1973; Karickhoff, Brown and Scott 1979). Briggs (1973) developed a regression equation for sorption of phenyl urea herbicides. The 
relationship between soil organic carbon and water partition coefficient (Koc) and the octanol/water partition coefficient (Kow) is presented in Equation 2.10:

$$
\log \mathrm{Koc}=0.524 \log \mathrm{Kow}+0.618
$$

The following equation for sorption of hydrophobic organic pollutants has been developed by Karickhoff, Brown and Scott (1979):

$$
\log \mathrm{Koc}=1.00 \log \text { Kow }-0.21
$$

where $\mathrm{Koc}$ is equal to $\mathrm{Kp} / \mathrm{OC}, \mathrm{Kp}$ is defined as the sediment-water partition coefficient (i.e., the ratio of sorbate concentration in the sediment phase over that in the equilibrium solution), and $O C$ is the fraction of organic carbon in the soil. The equation was for data on 10 hydrophobic compounds, with the log kows ranging from 2.1 to 6.3.

Hassett et al. (1980) investigated 13 soils and sediments and 14 test compounds to yield the following equation:

$$
\log \mathrm{Koc}=\log \text { Kow }-0.317
$$

Linear regression of the combined data sets of Brown and Flagg (1981) and Flagg (1981) and Karickhoff, Brown, and Scott (1979) resulted in the following empirical equation (Brown and Flagg 1981):

$$
\log \text { Koc }=0.937 \log \text { Kow }-0.006
$$

The inclusion of a more diverse group of chemicals (in terms of polarity and hydrophobicity) results in an increase in uncertainty, but a wider range of application. Predicted log Koc values at the $90 \%$ confidence level are \pm 0.209 at the low end of the curve (Brown and Flagg 1981), which includes the kow range of phenols. This value indicates the value of Koc may vary by a factor of 2.5 (at the $90 \%$ confidence level). 
An experimental value of the rate constant for soil uptake should be used if one is available. Neely (1979a) suggested that the rate of soil uptake is independent of the chemical and dependent directly on the properties of the soil. Neely (1979a) suggested a value of $0.68 \mathrm{~mL} /(\mathrm{g} / \mathrm{hr})$, which he used in simulations of the pesticide chlorphyrifos.

The kinetics of organic compound adsorption by sediments are not commonly measured. Only the distribution of the compound between solution and solid at equilibrium is given. Smith et al. (1978) estimated uptake rates for sediments based on equilibrium sorption onto suspended sediments and a sedimentation rate. It was thus predicted that compounds with higher kows accumulated in sediment faster than less hydrophobic compounds. This information was used in developing the following relationship for uptake rate as a function of Kow:

$$
K 21=4.0 \times 10^{-5} * \log K_{0} w^{6.86}
$$

where $\mathrm{K} 21$ is a turnover rate from water to sediment $[\mathrm{mL} /(\mathrm{g} \star \mathrm{hr})]$. This turnover rate is adjusted by quantities of sediment and water to calculate a rate constant, $\mathrm{K} 21(1 / \mathrm{hr})$. This is an order of magnitude estimate to be used only when there are no data on the transient behavior of sediment uptake of compounds. Uptake of phenolics by sediment is not a pathway of major importance, based on the $\mathrm{Kp}$ values (estimated from Kows) of 12 phenolics considered. A more sophisticated method for predicting absorption rates may be necessary for predicting the fate of more hydrophobic materials, such as PAHs, for which adsorption onto sediments is more important. Testing the model of diffusion into sediment and addition of a suspended sediment compartment may be the next steps in modeling sediment interactions.

The rate of release from sediment, if not known, is based on the uptake rate and equilibrium values, as estimated by the following equation:

$$
K 12=K 21 / K O C * O C
$$


where $\mathrm{K} 12$ = rate of transfer from sediment to water $(1 / \mathrm{hr})$

$\mathrm{K} 21$ = rate of transfer from water to sediment, turnover rate $x$ sediment/water ratio (1/hr)

Koc = soil organic carbon/water partitioning coefficient

$O C=$ percent of organic carbon in the sediment.

This method may underestimate the retention time if the process is not reversible.

\subsection{VOLATILIZATION}

The evaporation rate constant (volatilization) used in APM is based on a calculation using water solubility, vapor pressure, and molecular weight. The rate constant, K41, is calculated in equation 2.16 (Neely 1979a):

$$
1 / K 41=\left(7.53 \times 10^{-3} \sqrt{M}\right)+\left[(T * S / P * \sqrt{M}) *\left(4.91 \times 10^{-6}\right)\right]
$$

where $K 41=$ rate of transfer between water and air per $\mathrm{cm}$

$$
\begin{aligned}
& M=\text { molecular weight of the chemical } \\
& T=\text { temperature in degrees } K \\
& S=\text { solubility in } \mu \mathrm{g} / \mathrm{g} \\
& P=\text { pressure in } \mathrm{mm} \mathrm{Hg} .
\end{aligned}
$$

A lack of vapor pressure data at ambient temperatures for some complex phenolic compounds limits the use of this relationship. Vapor pressure of some compounds was estimated by extrapolating boiling point vs. vapor pressure relationships below the temperatures intended. Other methods of calculating volatilization rates are described in Smith et al. (1977).

\subsection{OTHER PROCESSES}

Fate of chemicals in aquatic environments may involve a variety of chemical transformations which could be considered, but are not presently included, in APM. Some examples are discussed below. 


\subsubsection{Hydrolysis}

The hydrolysis rate of a compound generally depends on temperature and $\mathrm{pH}$ of the aquatic system. The hydrolysis rate for phenols under investigation is assumed to be zero, because they contain no hydrolyzable functional groups.

\subsubsection{Oxidation}

Two major types of photo-oxidation reactions of simple phenols are dimerization and hydroxylation. The resultant products are dihydroxybiphenyls and dihydroxybenzenes. Free radical oxidation of para-cresol was examined by Smith et al. (1978). The value of the oxidation rate constant was small relative to biodegradation. The oxidation half-life of para-cresol was about one year. oxidation was assumed to be a minor factor in the fate of phenolics and was studied no further.

\subsubsection{Biotransformation}

Transformation of a chemical species taken up by fish should be evaluated. Fish have been shown to detoxify phenolic compounds to some extent by sulfate conjugation (Kobayashi and Akitake 1975). In uptake experiments, most of the phenol absorbed initially was excreted in free-form. Subsequent excretion was slower and contained more bound phenol. Metabolism of phenol by fathead minnows was studied by Call, Brooke and Lu (1980) who found that minor amounts of phenol were unmetalbolized at the end of a 28-day depuration period. The bound phenol may react differently in the environment than does the corresponding free form. Because uptake of the phenolic compounds under study is such a small fraction of the total inventory of these chemicals, and because few data were available, the biotransformation pathway was not studied further. Biotransformation is, however, important for its potential transfer to humans. A metabolite compartment exists in APM and will be included in future work. 


\subsection{FUEL SPILL SIMULATION}

Production and transportation of synthetic fuels will result in releases of complex organic materials to the environment. The Aquatic Pathways Model can be used to simulate spills and assess the fate of individual constituents of complex materials.

Spill incident patterns can be approximated by using historical data on crude oil and product spills of crude oil. Adjustment for ocean spills must be made for inland transport. Major spill sources are anticipated to be tank barges, bulk transfer points, pipelines, railroads, and highways. Most waterborne transport will probably be by barges. Spill factors based on oil spills are estimated at about 10 to $20 \times 10^{-6}$ (gal/gal handled) for transportation and transfer (Petty et al. 1982).

The APM was used to simulate spills of a representative coal liquid (SRC-II fuel oil blend) into both a pond and a river system. The fate of the phenolic components of this material, as estimated by the code, is discussed in this chapter. Predictions made by APM are based on rate constants adapted from various sources in the literature. These values and their applicability have not been confirmed. Validation of the model will be an important step in its future development.

\subsection{CASES}

In the first group of cases, a 100-1iter (26-gal) spill of SRC-II was simulated over 30 hours. Spills of this size are common occurrences; about half of the 17,500 oil spills in the U.S. waters reported in 1980 and 1981 were under 50 gallons (U.S. Department of Transportation 1982). The receiving waters were assumed to be either a $100,000 \mathrm{~m}^{3}\left(1 \times 10^{8}\right.$ liter $)$ pond, or a river with a flow rate of $1,000 \mathrm{~m}^{3} / \mathrm{hr}$. The amount of each phenolic compound released into the water is based on the composition given in Table 1.1. A spill of 10,000 liters (2600 gal) of SRC-II into the same size pond was simulated and followed for 100 hours. About $25 \%$ of all $0 i l$ spills are this size or larger.

An additional case involving a spill of 160,000 liters (about 42,000 gallons or 1000 barrels) of SRC liquid into a large river was also simulated. 
This case corresponds to a moderate sized tank barge spill; approximately 1000 tank barge spills occurred each year from 1977 through 1981, averaging 1000 to 6000 gal each (U.S. Department of Transportation 1982; Petty et al. 1982). The flow rate of the river in this simulation, $12 \mathrm{million} \mathrm{m}^{3} / \mathrm{hr}$, is about that of the Columbia River. This simulation was run for 100 hours.

\subsection{RESULTS}

Distribution of 12 phenolic components from a simulated spill of SRC-II into a pond is shown in Table 3.1. Biodegradation was predicted to be the most important removal mechanism for these compounds, accounting for removal of about two-thirds of the compounds 30 hours after the spill. Biodegradation of the most complex phenolics, including C5-phenol, 5-indanol, and C1-indanol, was not estimated but may also be significant.

Photolysis was a minor pathway, based on estimates of photolysis rate constants. Photolysis accounted for the fate of about $1 \%$ of the compounds. Photolysis was a significant pathway for resorcinol, accounting for removal of about $7 \%$ in the simulation. Volatilization was also a minor loss mechanism for this class of compounds. Uptake by fish and loss to sediment were generally minor pathways, accounting for less than $0.1 \%$ of the fate of every compound studied. Distribution of the compounds in sediment ranged from less than $0.0001 \%$ for phenol to $0.02 \%$ for C5-phenol.

\subsubsection{Simulations of Para-Cresol and Naphthol Components of Pond Scenarios}

The para-cresol in each model compartment as a function of time for a 100-liter spill into a pond is shown in Table 3.2 and Figure 3.1. In the 30hour simulation, the concentration of para-cresol is reduced to $16 \%$ of its original value, from $17 \mu \mathrm{g} / \mathrm{L}$ to $2.8 \mu \mathrm{g} / \mathrm{L}$. Most of the para-cresol (80\%) is biodegraded in 30 hours. Amounts of chemical in the sediment, fish, and air (volatilization) compartments are too small to show up in Figure 3.1 , a linearscale plot.

The concentration of fish in the pond is assumed to be 1 gram of fish per cubic meter of water, or $100 \mathrm{~kg}$ of fish in the entire $1 \times 10^{8}$ liter pond. Less than $0.001 \%$ of the para-cresol is taken up by the fish, with the concentration 
TABLE 3.1. Distribution of Phenolic Compounds 30 Hours After Simulated SRC-II Spill into a Pond

Percent of Each Compound in Compartment

\begin{tabular}{|c|c|c|c|c|c|c|}
\hline Compound & Water & Sediment & Fish & Air & Biodegr. & Photolysis \\
\hline Phenol & 23 & $<0.0001$ & 0.0002 & 0.6 & 76 & 0.4 \\
\hline o-cresol & 19 & 0.0001 & 0.0004 & 1 & 78 & 1 \\
\hline p-cresol & 16 & 0.0001 & 0.0003 & $0.06(a)$ & 80 & 3 \\
\hline m-cresol & 25 & 0.0001 & 0.0005 & 0.9 & 73 & 1 \\
\hline C2-phenol & 24 & 0.0003 & 0.001 & $--(b)$ & 76 & -- \\
\hline C3-phenol & 57 & 0.003 & 0.003 & -- & 43 & -- \\
\hline C4-phenol & 76 & 0.006 & 0.006 & -- & 24 & - \\
\hline C5-phenol & $99+$ & 0.02 & 0.009 & -- & -- & - \\
\hline 5-Indanol & 99 & 0.002 & 0.004 & -- & - & 1 \\
\hline Cl-Indanol & 99 & 0.009 & 0.007 & -- & - & 1 \\
\hline Resorcinol & 57 & $<0.0001$ & 0.0002 & 0.0004 & 37 & 7 \\
\hline Naphthol & 72 & 0.002 & 0.004 & 0.3 & 26 & 2 \\
\hline Average & 33 & 0.001 & 0.002 & 0.3 & 66 & 1 \\
\hline
\end{tabular}

(a) Rates constant based on Smith et al. (1978) ratio volatilization rate and oxygen reaeration rate.

(b) Rate constant for this process not estimated for this compound. Data not available.

TABLE 3.2. Fate of Para-Cresol in a 30-Hour Pond Simulation

(amount in each compartment, grams)

\begin{tabular}{|c|c|c|c|c|c|c|c|}
\hline - & - & -------- & ---- & -- & $--\cdots---n$ & $----n--$ & 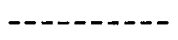 \\
\hline Time (hr) & WATER & SEDIMENT & FISH & $A I R$ & B IODEGRADE & PHOTOLYSIS & TOTAL \\
\hline$-\ldots \ldots$ & $\ldots$ & $--n--n$ & $\ldots \ldots$ & -- & $-\ldots-1$ & -- & \\
\hline $0.30 E+00$ & $0.17 E+04$ & $0.54 E-04$ & $0.15 E-02$ & $0.20 E-01$ & $0.29 E+02$ & $0.12 \mathrm{E}+01$ & $0.17 E+04$ \\
\hline $0.33 E+01$ & $0.14 E+04$ & $0.54 E-03$ & $0.11 \mathrm{E}-01$ & $0.20 E+00$ & $0.30 E+03$ & $0.12 E+02$ & $0.17 E+04$ \\
\hline $0.63 \mathrm{E}+01$ & $0.12 E+04$ & $0.93 E-03$ & $0.15 E-01$ & $0.36 E+00$ & $0.52 E+03$ & $0.21 E+02$ & $0.17 E+04$ \\
\hline $0.93 E+01$ & $0.97 E+03$ & $0.12 E-02$ & $0.15 \mathrm{E}-01$ & $0.48 E+00$ & $0.70 E+03$ & $0.29 E+02$ & $0.17 E+04$ \\
\hline $0.12 E+02$ & $0.81 E+03$ & $0.15 \mathrm{E}-02$ & $0.14 \mathrm{E}-01$ & $0.59 E+00$ & $0.86 E+03$ & $0.35 E+02$ & $0.17 E+04$ \\
\hline $0.15 E+02$ & $0.68 E+03$ & $0.17 E-02$ & $0.13 E-01$ & $0.68 \mathrm{E}+00$ & $0.99 \mathrm{E}+03$ & $0.41 E+02$ & $0.17 E+04$ \\
\hline $0.18 E+02$ & $0.56 E+03$ & $0.18 \mathrm{E}-02$ & $0.11 E-01$ & $0.75 E+00$ & $0.11 E+04$ & $0.45 E+02$ & $0.17 E+04$ \\
\hline $0.21 E+02$ & $0.47 E+03$ & $0.19 E-02$ & $0.94 E-02$ & $0.82 E+00$ & $0.12 E+04$ & $0.49 E+02$ & $0.17 E+04$ \\
\hline $0.24 E+02$ & $0.39 E+03$ & $0.20 E-02$ & $0.79 E-02$ & $0.87 E+00$ & $0.13 \mathrm{E}+04$ & $0.52 E+02$ & $0.17 E+04$ \\
\hline $0.27 E+02$ & $0.33 E+03$ & $0.21 E-02$ & $0.67 E-02$ & $0.91 E+00$ & $0.13 \mathrm{E}+04$ & $0.55 E+02$ & $0.17 E+04$ \\
\hline $0.30 E+02$ & $0.28 E+03$ & $0.21 E-02$ & $0.57 E-02$ & $0.94 E+00$ & $0.14 E+04$ & $0.57 E+02$ & $0.17 E+04$ \\
\hline$-----1--1$ & 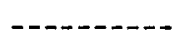 & $-\infty--\infty-\cdots$ & -------- & $-\cdots-----$ & $-\cdots----$ & ------ & - \\
\hline Final \% & $0.16 E+02$ & $0.12 \mathrm{E}-03$ & $0.33 E-03$ & $0.55 E-01$ & $0.80 \mathrm{E}+02$ & $0.33 \mathrm{E}+01$ & \\
\hline Conc $(\mu g / g)$ & $0.28 \mathrm{E}-02$ & $0.83 E-03$ & $0.57 E-01$ & & & & \\
\hline .. & - - - - - - - &.-- & -....... & ---- & 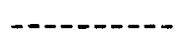 & -- & - - - \\
\hline
\end{tabular}




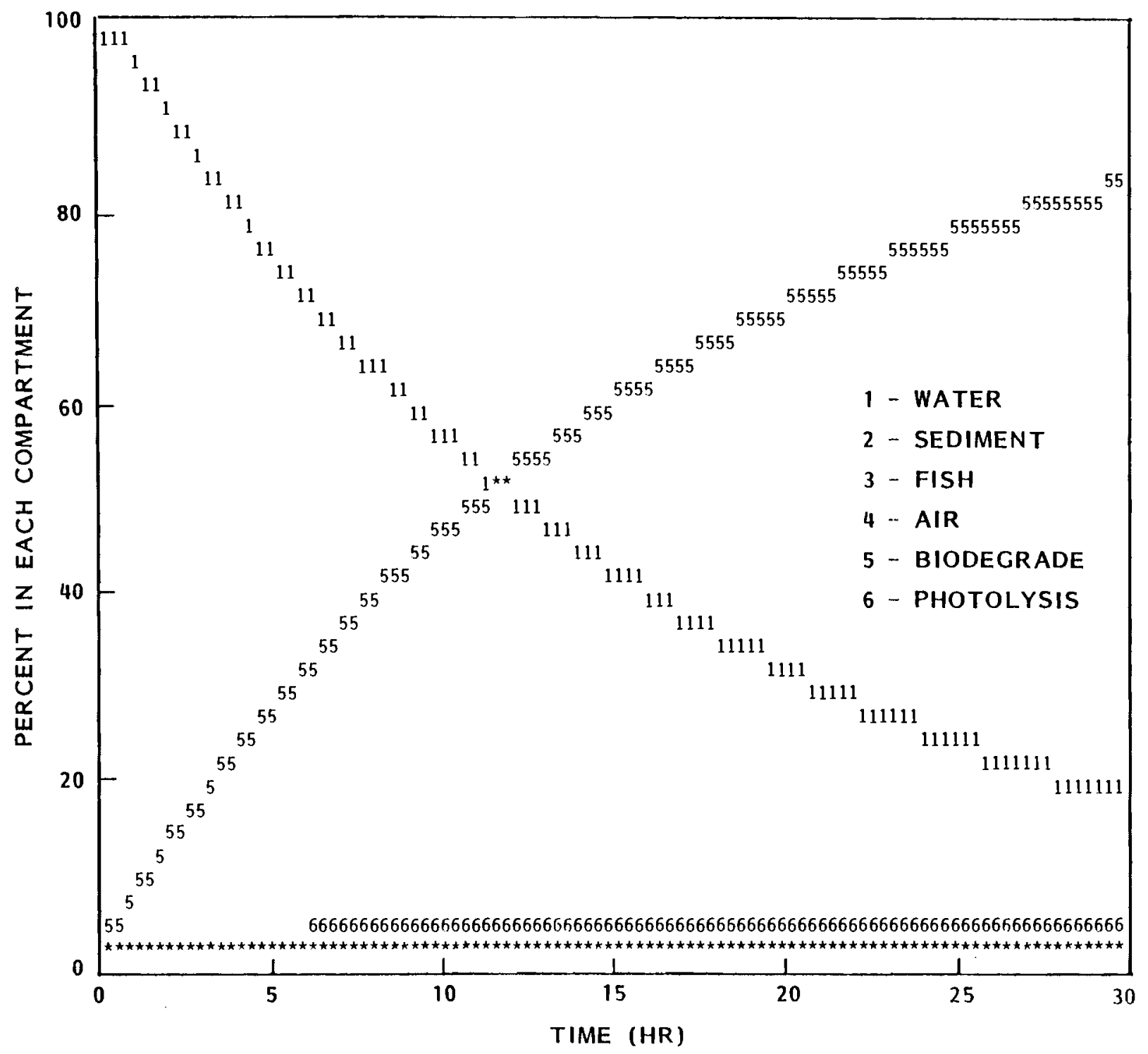

FIGURE 3.1. Fate of Para-Cresol in a 30-Hour Pond Simulation

reaching a maximum of $0.15 \mu \mathrm{g} / \mathrm{g}$ fish about 7 hours after exposure and declining to about $0.06 \mu \mathrm{g} / \mathrm{g}$ at 30 hours. The concentration of para-cresol in fish is shown in Figure 3.2. The simulation shows that at 30 hours, the concentration of para-cresol in sediment has leveled off at $0.0008 \mu \mathrm{g} / \mathrm{g}$, and the concentration in the water decreased to $0.003 \mu \mathrm{g} / \mathrm{g}$.

The fate of naphthol in the 30 -hour pond simulation is shown in Table 3.3 and Figure 3.3. Naphthol was degraded much more slowly than para-cresol; in 30 hours, only about $26 \%$ of the initial amount of naphthol was biodegraded, 


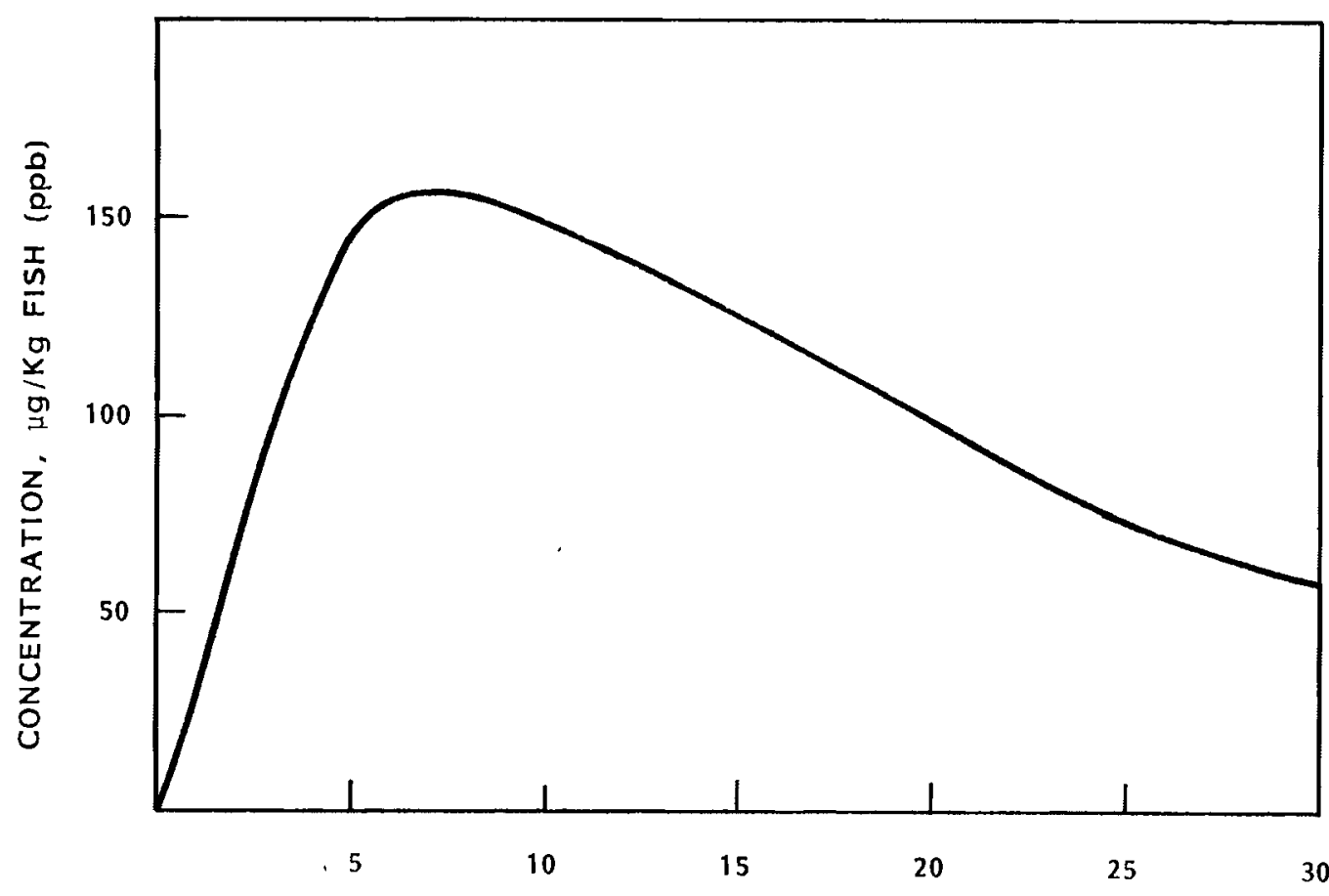

TIME, HR

FIGURE 3.2. Concentration of Para-Cresol in Fish from Pond Simulation

TABLE 3.3. Fate of Naphthol in a 30-Hour Pond Simulation

\begin{tabular}{|c|c|c|c|}
\hline $2-1-2-1$ & $-2-0-1$ & $2-10-2$ & 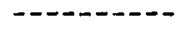 \\
\hline Time (hr) & WATER & SEDIMENT & FISH \\
\hline--------- & $-\cdots+-\cdots$ & 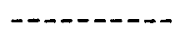 & $\cdots$ \\
\hline $0.30 E+00$ & $0.40 E+02$ & $0.15 E-04$ & $0.57 \mathrm{E}-04$ \\
\hline $0.33 E+01$ & $0.39 E+02$ & $0.16 \mathrm{E}-03$ & $0.53 \mathrm{E}-03$ \\
\hline $0.63 E+01$ & $0.37 \mathrm{E}+02$ & $0.29 E-03$ & $0.86 \mathrm{E}-03$ \\
\hline $0.93 E+01$ & $0.36 \mathrm{E}+02$ & $0.41 E-03$ & $0.11 E-02$ \\
\hline $0.12 E+02$ & $0.35 E+02$ & $0.51 E-03$ & $0.12 E-02$ \\
\hline $0.15 E+02$ & $0.34 E+02$ & $0.60 E-03$ & $0.13 E-02$ \\
\hline $0.18 E+02$ & $0.33 E+02$ & $0.68 E-03$ & $0.14 \mathrm{E}-02$ \\
\hline $0.21 E+02$ & $0.32 E+02$ & $0.75 E-03$ & $0.14 \mathrm{E}-02$ \\
\hline $0.24 E+02$ & $0.31 E+02$ & $0.82 E-03$ & $0.14 E-02$ \\
\hline $0.27 \mathrm{E}+02$ & $0.30 E+02$ & $0.87 E-03$ & $0.14 E-02$ \\
\hline $0.30 E+02$ & $0.29 E+02$ & $0.91 E-03$ & $0.14 E-02$ \\
\hline$---------\infty$ & $-\cdots-\cdots-\cdots$ & $---\cdots---\cdots$ & $\cdots-\cdots-\cdots$ \\
\hline Final \% & $0.72 E+02$ & $0.23 \mathrm{E}-02$ & $0.35 \mathrm{E}-02$ \\
\hline Conc $(u g / g)$ & $0.29 E-03$ & $0.36 E-03$ & $0.14 \mathrm{E}-01$ \\
\hline$\ldots$ & - & $\cdots$ & 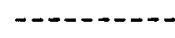 \\
\hline
\end{tabular}

AIR

AIR

$0.16 \mathrm{E}-02$

$0.17 \mathrm{E}-01$

$0.33 \mathrm{E}-01$

$0.47 \mathrm{E}-01$

$0.61 \mathrm{E}-01$

$0.75 \mathrm{E}-01$

$0.89 \mathrm{E}-01$

$0.10 E+00$

$0.11 E+00$

$0.13 \mathrm{E}+00$

$0.14 \mathrm{E}+00$

$0.34 \mathrm{E}+00$
BIODEGRADE PHOTOLYSIS TOTAL

$0.12 \mathrm{E}+00$

$0.13 E+01$

$0.24 E+01$

$0.35 \mathrm{E}+01$

$0.46 E+01$

$0.56 \mathrm{E}+01$

$0.66 \mathrm{E}+01$

$0.76 \mathrm{E}+01$

$0.85 \mathrm{E}+01$

$0.95 \mathrm{E}+01$

$0.10 \mathrm{E}+02$

$0.26 E+02$

$0.86 \mathrm{E}-02$

$0.93 E-01$

$0.18 \mathrm{E}+00$

$0.25 \mathrm{E}+00$

$0.33 \mathrm{E}+00$

$0.41 \mathrm{E}+00$

$0.48 \mathrm{E}+00$

$0.55 \mathrm{E}+00$

$0.62 E+00$

$0.68 \mathrm{E}+00$

$0.74 E+00$

$0.18 E+01$
$0.40 \mathrm{E}+02$

$0.40 E+02$

$0.40 \mathrm{E}+02$

$0.40 \mathrm{E}+02$

$0.40 \mathrm{E}+02$

$0.40 E+02$

$0.40 \mathrm{E}+02$

$0.40 E+02$

$0.40 \mathrm{E}+02$

$0.40 E+02$

$0.40 \mathrm{E}+02$ 


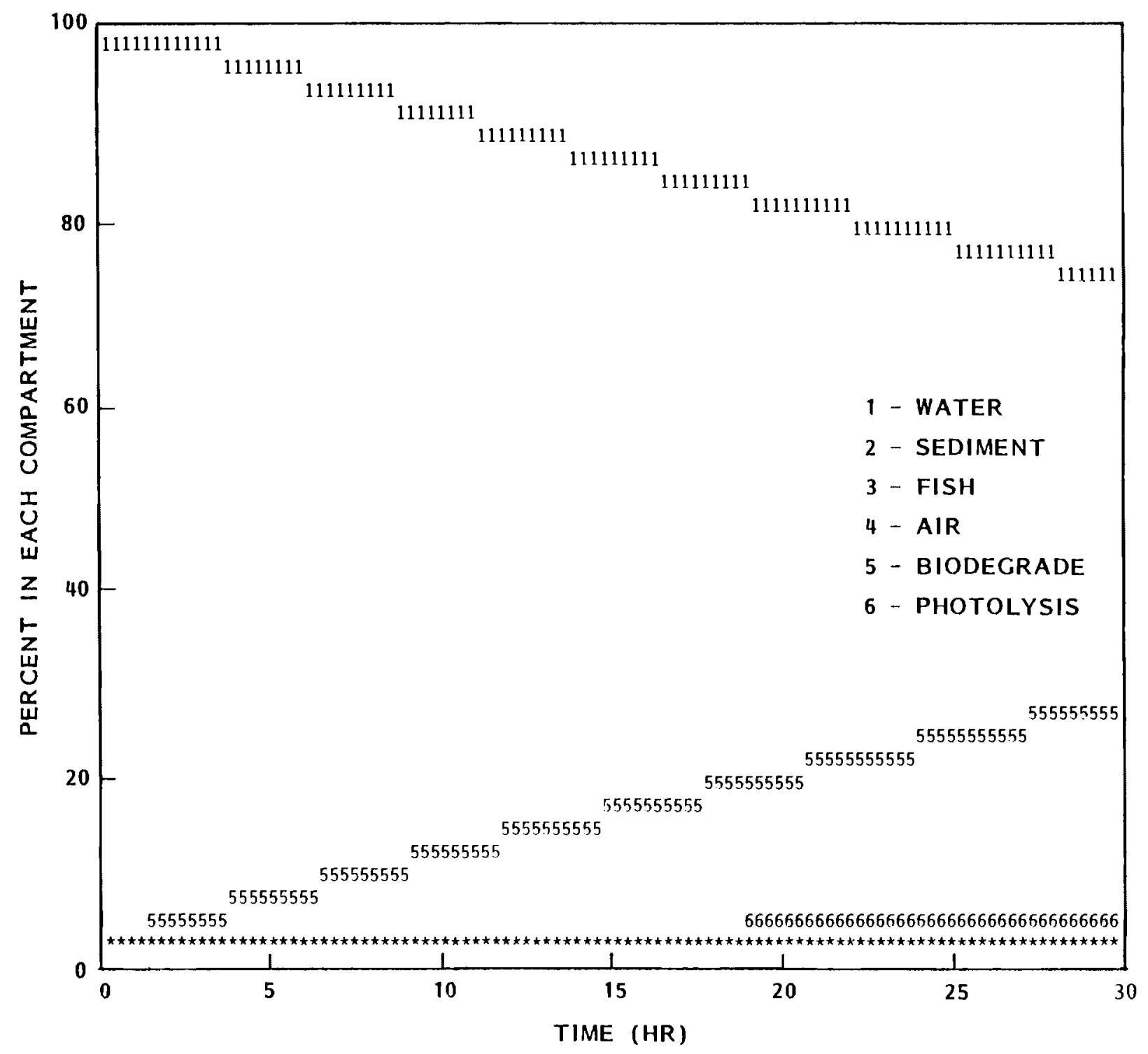

FIGURE 3.3. Fate of Naphthol in a 30-Hour Pond Simulation

whereas $80 \%$ of the para-cresol was degraded. A greater percentage of the compound was taken up by fish and sediment. Fish and sediment took up $0.004 \%$ and $0.002 \%$, respectively, of the naphthol, compared with $0.001 \%$ (max.) and $0.0001 \%$ of para-cresol. Maximum naphthol concentrations of $0.01 \mu \mathrm{g} / \mathrm{g}$ fish and $0.0004 \mu \mathrm{g} / \mathrm{g}$ sediment were reached in the simulations. Photolys is eliminated about $20 \%$ of the naphthol in the 30 -hour simulation. The concentration in fish reached $0.01 \mu \mathrm{g} / \mathrm{g}$ tissue, while the water concentration fell to $0.0003 \mu \mathrm{g} / \mathrm{g}$. 
In the simulation of a 10,000-liter spill of SRC-II into a small pond, the initial concentration of SRC-II was $0.01 \%$. This is one-hundreth the values given in Table 1.1 , or about $10.6 \mathrm{mg} / \mathrm{L}$ total phenolics. The phenolic content dropped quickly, as demonstrated by the results of the para-cresol simulation given in Table 3.4. After one day, the concentration was about $24 \%$ of initial concentration; after 2 days, $6 \%$; 3 days, about 1\%; and 4 days, $0.3 \%$.

In the 100-hour simulation, the concentration of para-cresol reached a maximum of $15 \mu \mathrm{g} / \mathrm{g}(\mathrm{ppm})$ in $\mathrm{fish}$, and $0.08 \mathrm{\mu g} / \mathrm{g}$ in the sediment. Figure 3.4 is a plot of amount of para-cresol in each compartment as a function of time for this scenario. Biodegradation was again the fate of most of the para-cresol. Photolysis, the fate of $4 \%$ of of the para-cresol, is also shown in the figure. At the end of the simulation, water, fish and sediment concentrations had decreased to $0.004,0.08$, and $0.05 \mu \mathrm{g} / \mathrm{g}$, respectively.

\subsubsection{Simulation of Para-Cresol in a River Scenario}

The simulation of the para-cresol component of a 1000-barrel spill of SRC-II fuel blend into a river the size of the Columbia River is shown in Tables 3.5 and 3.6 . The flow rate of the river was $1.21 \times 10^{7} \mathrm{~m}^{3} / \mathrm{hr}$, and the volume of each reach was $4.1 \times 10^{6} \mathrm{~m}^{3}$ (1800 $\mathrm{m}$ long, $450 \mathrm{~m}$ wide, $5 \mathrm{~m}$ deep). Each reach contained $410 \mathrm{~kg}$ of fish, weighing an average of $100 \mathrm{~g}$ each, and

TABLE 3.4. Simulation of Para-Cresol Component of a 10,000-L SRC-II Spill into a Pond

\begin{tabular}{|c|c|c|c|c|c|c|c|}
\hline-------- & -------- & 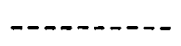 & -7 & - & - & - & \\
\hline Time $(h r)$ & WATER & SEDIMENT & FISH & AIR & BIODEGRADE & PHOTOLYSIS & TOTAL \\
\hline$--\cdots+-\cdots$ & -------- & 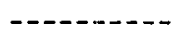 & $\ldots+\ldots$ & $-\cdots$ & $----n$ & - & \\
\hline $0.10 E+01$ & $0.16 \mathrm{E}+06$ & $0.18 E-01$ & $0.46 E+00$ & $0.66 \mathrm{E}+01$ & $0.96 E+04$ & $0.40 E+03$ & $0.17 E+06$ \\
\hline $0.11 E+02$ & $0.88 E+05$ & $0.14 E+00$ & $0.15 E+01$ & $0.55 E+02$ & $0.79 E+05$ & $0.33 E+04$ & $0.17 E+06$ \\
\hline $0.21 E+02$ & $0.48 E+05$ & $0.19 E+00$ & $0.95 E+00$ & $0.81 E+02$ & $0.12 E+06$ & $0.49 E+04$ & $0.17 E+06$ \\
\hline $0.31 E+02$ & $0.26 E+05$ & $0.21 E+00$ & $0.54 E+00$ & $0.95 \mathrm{E}+02$ & $0.14 E+06$ & $0.57 E+04$ & $0.17 E+06$ \\
\hline $0.41 E+02$ & $0.14 E+05$ & $0.21 E+00$ & $0.30 E+00$ & $0.10 E+03$ & $0.15 E+06$ & $0.62 E+04$ & $0.17 \mathrm{E}+06$ \\
\hline $0.51 E+02$ & $0.78 E+04$ & $0.20 E+00$ & $0.16 E+00$ & $0.11 E+03$ & $0.16 E+06$ & $0.65 \mathrm{E}+04$ & $0.17 E+06$ \\
\hline $0.61 E+02$ & $0.43 E+04$ & $0.19 E+00$ & $0.89 E-01$ & $0.11 E+03$ & $0.16 E+06$ & $0.66 E+04$ & $0.17 E+06$ \\
\hline $0.71 E+02$ & $0.23 E+04$ & $0.17 E+00$ & $0.48 \mathrm{E}-01$ & $0.11 E+03$ & $0.16 E+06$ & $0.67 E+04$ & $0.17 E+06$ \\
\hline $0.81 E+02$ & $0.13 E+04$ & $0.16 E+00$ & $0.26 E-01$ & $0.11 E+03$ & $0.16 E+06$ & $0.67 E+04$ & $0.17 E+06$ \\
\hline $0.91 E+02$ & $0.70 E+03$ & $0.14 \mathrm{E}+00$ & $0.14 \mathrm{E}-01$ & $0.11 E+03$ & $0.16 E+06$ & $0.67 E+04$ & $0.17 E+06$ \\
\hline $0.10 \mathrm{E}+03$ & $0.40 E+03$ & $0.13 \mathrm{E}+00$ & $0.84 \mathrm{E}-02$ & $0.11 F+03$ & $0.16 E+06$ & $0.68 E+04$ & $0.17 E+06$ \\
\hline---------- & $------\cdots$ & -------- & $----\cdots---$ & $-\cdots+\cdots---$ & -------- & - & -- \\
\hline Final \% & $0.24 E+00$ & $0.76 E-04$ & $0.49 E-05$ & $0.66 \mathrm{E}-01$ & $0.96 \mathrm{E}+02$ & $0.40 E+01$ & \\
\hline Conc (ug/g) & $0.40 E-02$ & $0.52 \mathrm{E}-01$ & $0.84 \mathrm{E}-01$ & & & & \\
\hline 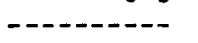 & --- & . & 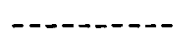 & - - & -- & - & 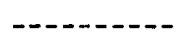 \\
\hline
\end{tabular}




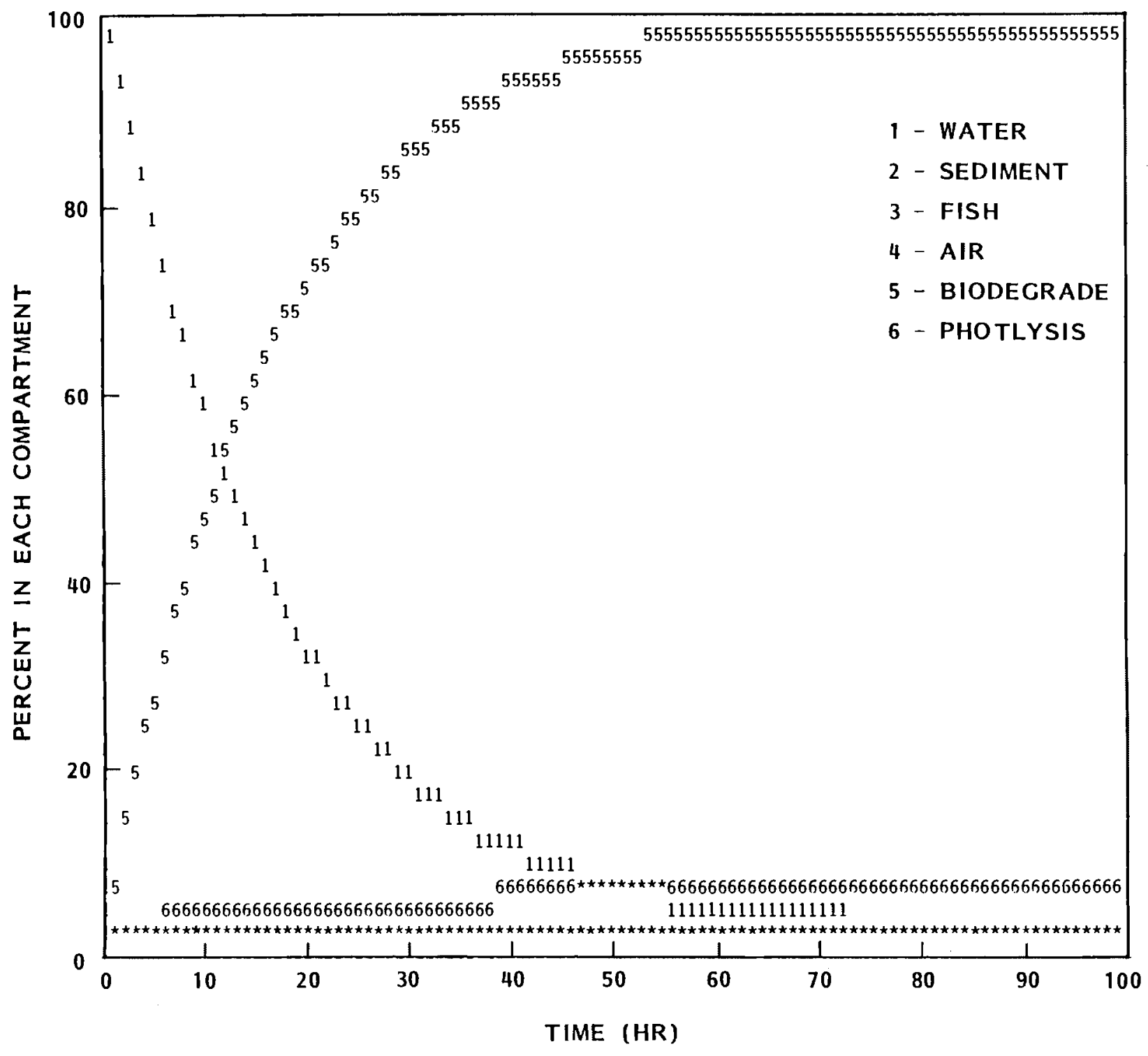

FIGURE 3.4. Fate of Para-Cresol Component of a 10,000 L SRC-II Spill into a Pond

$2 \times 10^{7} \mathrm{~kg}$ of active sediment containing $1 \%$ organic matter. Tables 3.5 and 3.6 give amount of para-cresol (in grams) in each compartment in the first 20 reaches of the river at 20 hours (Table 3.5) and 100 hours (Table 3.6) after a spi11. For bookkeeping purposes, the "chemical" column shows the total amount of available in each reach.

Comparison of Tables 3.5 and 3.6 shows that amounts of SRC-II in the water and the fish decrease rapidly, while sediment retains the compound somewhat 
TABLE 3.5. Simulation of Para-Cresol Component of SRC-II in River $20 \mathrm{Hr}$ After a Spill (amount in each compartment, grams)

\begin{tabular}{rc} 
Reach No. & Chemical \\
\hdashline 1 & $0.21 \mathrm{E}+06$ \\
2 & $0.19 \mathrm{E}+06$ \\
3 & $0.18 \mathrm{E}+06$ \\
4 & $0.16 \mathrm{E}+06$ \\
5 & $0.15 \mathrm{E}+06$ \\
6 & $0.14 \mathrm{E}+06$ \\
7 & $0.13 \mathrm{E}+06$ \\
8 & $0.12 \mathrm{E}+06$ \\
9 & $0.11 \mathrm{E}+06$ \\
10 & $0.11 \mathrm{E}+06$ \\
11 & $0.11 \mathrm{E}+06$ \\
12 & $0.11 \mathrm{E}+06$ \\
13 & $0.11 \mathrm{E}+06$ \\
14 & $0.11 \mathrm{E}+06$ \\
15 & $0.11 \mathrm{E}+06$ \\
16 & $0.10 \mathrm{E}+06$ \\
17 & $0.97 \mathrm{E}+05$ \\
18 & $0.90 \mathrm{E}+05$ \\
19 & $0.80 \mathrm{E}+05$ \\
20 & $0.69 \mathrm{E}+05$
\end{tabular}

\begin{tabular}{l} 
WATER \\
\hdashline $0.76 E+00$ \\
$0.26 E+01$ \\
$0.12 E+02$ \\
$0.52 E+02$ \\
$0.19 E+03$ \\
$0.57 E+03$ \\
$0.15 E+04$ \\
$0.32 E+04$ \\
$0.63 E+04$ \\
$0.11 E+05$ \\
$0.17 E+05$ \\
$0.25 E+05$ \\
$0.34 E+05$ \\
$0.43 E+05$ \\
$0.51 E+05$ \\
$0.56 E+05$ \\
$0.59 E+05$ \\
$0.58 E+05$ \\
$0.55 E+05$ \\
$0.50 E+05$
\end{tabular}

\begin{tabular}{l}
\hline$-\cdot-5 E D I M E N T$ \\
\hdashline $0.59 E+02$ \\
$0.55 E+02$ \\
$0.51 E+02$ \\
$0.48 E+02$ \\
$0.45 E+02$ \\
$0.42 E+02$ \\
$0.39 E+02$ \\
$0.36 E+02$ \\
$0.34 E+02$ \\
$0.31 E+02$ \\
$0.29 E+02$ \\
$0.26 E+02$ \\
$0.24 E+02$ \\
$0.21 E+02$ \\
$0.18 E+02$ \\
$0.15 E+02$ \\
$0.13 E+02$ \\
$0.10 E+02$ \\
$0.83 E+01$ \\
$0.64 E+01$
\end{tabular}

\begin{tabular}{l}
\hline FISH \\
\hline $0.21 E-01$ \\
$0.25 E-01$ \\
$0.30 E-01$ \\
$0.36 E-01$ \\
$0.43 E-01$ \\
$0.51 E-01$ \\
$0.61 E-01$ \\
$0.71 E-01$ \\
$0.82 E-01$ \\
$0.93 E-01$ \\
$0.10 E+00$ \\
$0.11 E+00$ \\
$0.11 E+00$ \\
$0.11 E+00$ \\
$0.11 E+00$ \\
$0.10 E+00$ \\
$0.92 E-01$ \\
$0.80 E-01$ \\
$0.67 E-01$ \\
$0.55 E-01$
\end{tabular}

\begin{tabular}{l} 
AIR \\
\hdashline $0.27 E+02$ \\
$0.25 E+02$ \\
$0.23 E+02$ \\
$0.21 E+02$ \\
$0.20 E+02$ \\
$0.18 E+02$ \\
$0.17 E+02$ \\
$0.15 E+02$ \\
$0.14 E+02$ \\
$0.13 E+02$ \\
$0.12 E+02$ \\
$0.11 E+02$ \\
$0.95 E+01$ \\
$0.84 E+01$ \\
$0.72 E+01$ \\
$0.61 E+01$ \\
$0.51 E+01$ \\
$0.41 E+01$ \\
$0.32 E+01$ \\
$0.25 E+01$
\end{tabular}

\begin{tabular}{l} 
BIODEGRADE \\
\hdashline $0.20 E+06$ \\
$0.18 E+06$ \\
$0.17 E+06$ \\
$0.16 E+06$ \\
$0.14 E+06$ \\
$0.13 E+06$ \\
$0.12 E+06$ \\
$0.11 E+06$ \\
$0.10 E+06$ \\
$0.95 E+05$ \\
$0.87 E+05$ \\
$0.78 E+05$ \\
$0.70 E+05$ \\
$0.61 E+05$ \\
$0.53 E+05$ \\
$0.45 E+05$ \\
$0.37 E+05$ \\
$0.30 E+05$ \\
$0.24 E+05$ \\
$0.18 E+05$
\end{tabular}

PHOTOLYSIS

$0.82 E+04$

$0.76 \mathrm{E}+04$

$0.70 E+04$

$0.64 \mathrm{E}+04$

$0.60 E+04$

$0.55 E+04$

$0.51 \mathrm{E}+04$

$0.47 E+04$

$0.43 E+04$

$0.39 E+04$

$0.36 \mathrm{E}+04$

$0.32 \mathrm{E}+04$

$0.29 \mathrm{E}+04$

$0.25 \mathrm{E}+04$

$0.22 E+04$

$0.19 \mathrm{E}+04$

$0.15 E+04$

$0.12 E+04$

$0.98 \mathrm{E}+03$

$0.76 \mathrm{E}+03$

TABLE 3.6. Simulation of Para-Cresol Component of SRC-II in a River $100 \mathrm{Hr}$ After a Spill (arnount in each compartment, grams)

\begin{tabular}{cc}
\hline Reach No. & Chemical \\
\hdashline 1 & $0.21 \mathrm{E}+06$ \\
2 & $0.19 \mathrm{E}+06$ \\
3 & $0.18 \mathrm{E}+06$ \\
4 & $0.17 \mathrm{E}+06$ \\
5 & $0.15 \mathrm{E}+06$ \\
6 & $0.14 \mathrm{E}+06$ \\
7 & $0.13 \mathrm{E}+06$ \\
8 & $0.12 \mathrm{E}+06$ \\
9 & $0.11 \mathrm{E}+06$ \\
10 & $0.10 \mathrm{E}+06$ \\
11 & $0.94 \mathrm{E}+05$ \\
12 & $0.86 \mathrm{E}+05$ \\
13 & $0.80 \mathrm{E}+05$ \\
14 & $0.73 \mathrm{E}+05$ \\
15 & $0.68 \mathrm{E}+05$ \\
16 & $0.62 \mathrm{E}+05$ \\
17 & $0.58 \mathrm{E}+05$ \\
18 & $0.53 \mathrm{E}+05$ \\
19 & $0.49 \mathrm{E}+05$ \\
20 & $0.45 \mathrm{E}+05$
\end{tabular}

\begin{tabular}{l} 
WATER \\
\hdashline $0.92 \mathrm{E}-01$ \\
$0.17 \mathrm{E}+00$ \\
$0.24 \mathrm{E}+00$ \\
$0.29 \mathrm{E}+00$ \\
$0.34 \mathrm{E}+00$ \\
$0.38 \mathrm{E}+00$ \\
$0.41 \mathrm{E}+00$ \\
$0.43 \mathrm{E}+00$ \\
$0.45 \mathrm{E}+00$ \\
$0.46 \mathrm{E}+00$ \\
$0.47 \mathrm{E}+00$ \\
$0.47 \mathrm{E}+00$ \\
$0.47 \mathrm{E}+00$ \\
$0.47 \mathrm{E}+00$ \\
$0.47 \mathrm{E}+00$ \\
$0.46 \mathrm{E}+00$ \\
$0.45 \mathrm{E}+00$ \\
$0.44 \mathrm{E}+00$ \\
$0.43 \mathrm{E}+00$ \\
$0.42 \mathrm{E}+00$
\end{tabular}

\begin{tabular}{ll}
\hline SEDIMENT & FISH \\
\hdashline $0.26 \mathrm{E}+02$ & $0.36 \mathrm{E}-06$ \\
$0.24 \mathrm{E}+02$ & $0.85 \mathrm{E}-06$ \\
$0.22 \mathrm{E}+02$ & $0.13 \mathrm{E}-05$ \\
$0.21 \mathrm{E}+02$ & $0.16 \mathrm{E}-05$ \\
$0.19 \mathrm{E}+02$ & $0.19 \mathrm{E}-05$ \\
$0.18 \mathrm{E}+02$ & $0.21 \mathrm{E}-05$ \\
$0.16 \mathrm{E}+02$ & $0.23 \mathrm{E}-05$ \\
$0.15 \mathrm{E}+02$ & $0.25 \mathrm{E}-05$ \\
$0.14 \mathrm{E}+02$ & $0.26 \mathrm{E}-05$ \\
$0.13 \mathrm{E}+02$ & $0.27 \mathrm{E}-05$ \\
$0.12 \mathrm{E}+02$ & $0.27 \mathrm{E}-05$ \\
$0.11 \mathrm{E}+02$ & $0.28 \mathrm{E}-05$ \\
$0.10 \mathrm{E}+02$ & $0.28 \mathrm{E}-05$ \\
$0.96 \mathrm{E}+01$ & $0.28 \mathrm{E}-05$ \\
$0.89 \mathrm{E}+01$ & $0.28 \mathrm{E}-05$ \\
$0.82 \mathrm{E}+01$ & $0.27 \mathrm{E}-05$ \\
$0.76 \mathrm{E}+01$ & $0.27 \mathrm{E}-05$ \\
$0.70 \mathrm{E}+01$ & $0.26 \mathrm{E}-05$ \\
$0.65 \mathrm{E}+01$ & $0.26 \mathrm{E}-05$ \\
$0.60 \mathrm{E}+01$ & $0.25 \mathrm{E}-05$
\end{tabular}

$0.28 E+02$
$0.25 E+02$
$0.23 E+02$
$0.22 E+02$
$0.20 E+02$
$0.18 E+02$
$0.17 E+02$
$0.16 E+02$
$0.14 E+02$
$0.13 E+02$
$0.12 E+02$
$0.11 E+02$
$0.10 E+02$
$0.96 E+01$
$0.89 E+01$
$0.82 E+01$
$0.75 E+01$
$0.69 E+01$
$0.64 E+01$
$0.59 E+01$

DIODECRADE BIODEGRADE PHOTOLYSIS $0.20 \mathrm{E}+06 \quad 0.84 \mathrm{E}+04$ $0.19 E+06 \quad 0.77 E+04$ $0.17 E+06 \quad 0.71 E+04$ $0.16 \mathrm{E}+06 \quad 0.66 \mathrm{E}+04$ $0.15 E+06 \quad 0.60 E+04$ $0.13 E+06 \quad 0.56 E+04$ $0.12 E+06 \quad 0.51 E+04$ $0.11 E+06 \quad 0.47 E+04$ $0.11 E+06 \quad 0.44 E+04$ $0.97 E+05 \quad 0.40 E+04$ $0.90 \mathrm{E}+05 \quad 0.37 \mathrm{E}+04$ $0.83 E+05 \quad 0.34 E+04$ $0.76 E+05 \quad 0.32 E+04$ $0.70 \mathrm{E}+05 \quad 0.29 \mathrm{E}+0 \dot{0} 4$ $0.65 \mathrm{E}+05 \quad 0.27 \mathrm{E}+04$ $0.60 \mathrm{E}+05 \quad 0.25 \mathrm{E}+04$ $0.55 E+05 \quad 0.23 E+04$ $0.51 \mathrm{E}+05 \quad 0.21 \mathrm{E}+04$ $0.47 \mathrm{E}+05 \quad 0.19 \mathrm{E}+04$ $0.43 E+05$

$0.18 \mathrm{E}+04$ 
longer. Table 3.6 shows a small peak in water and fish compartments in reaches 12 through 15. Release from sediment caused this increase in the amount of chemical present in water. Biodegradation was again predicted to be the fate of most of the compound.

The behavior of indanols was predicted based only on estimated octanolwater partition coefficients and UV absorption spectra. No published information on biodegradation of indanols was found. Since indanols, C4 phenols, and C5 phenols are among the most hydrophobic of the phenolic compounds found in SRC liquids, they are the most likely to persist longer in sediments and fish. Additional refinement of the Kow values and data on the biodegradation of these compounds is needed to fully assess their fate in aquatic systems. 


\subsection{ANILINES AND HETEROCYCLIC COMPOUNDS}

Anilines and nitrogen-containing heterocyclic compounds may be formed during the coal liquefaction process. Alkyl anilines and pyridines have been identified in SRC-II materials (Strand and Vaughan 1981). Primary amines of polycyclic aromatic hydrocarbons (PAHs) have been identified in SRC-II heavy distillate (Wilson, Pelroy and Cresto 1980). In addition, azaarenes and imino arenes such as carbazoles, acridines, and quinolines may be present in coal conversion products. The chemical structure of representative compounds is shown in Figure 4.1 .

Data found in the brief survey of nitrogen-containing heterocyclic compounds would make possible the inclusion of several of these compounds in the data base. A summary of the data collection follows.

Sorption properties of several nitrogen-containing chemicals were studied in detail by Hassett et al. (1980). Three amines were studied, including benzidine, 2-aminoanthracene, and 6-aminocrysene, and two azaarenes, acridine and 2,2'-biquinoline. Regression equations were used to produce koc values for these compounds.

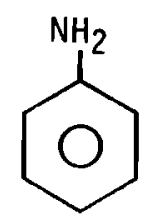

ANILINE

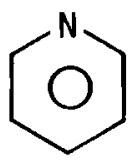

PYRIDINE<smiles>c1ccc2ncccc2c1</smiles>

QUINOLINE

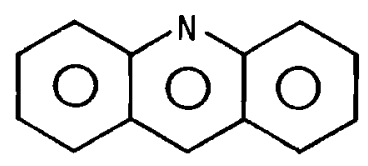

ACRIDINE

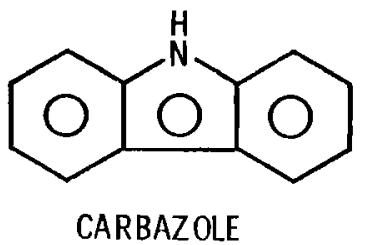

CARBAZOLE

FIGURE 4.1. Structure of Aniline and Representative NitrogenContaining Heterocyclic Compounds 
The fate of several nitrogen-containing aromatics was studied and modeled by Smith et a1. (1978). Compounds studied included quinoline, benzo[f] quinoline, 9H-carbazole, and 7H-dibenzo[c,g]-carbazole. Biodegradation and photolysis are the major pathways for elimination of these compounds. None of these compounds was shown to be persistent in the aquatic environment; halflives of the compounds in a one-compartment simulation ranged from 0.5 hour to 10 hours. Simulations of these chemicals could be run with the APM. However, this was outside the scope of the present study. Simulations with anilines and heterocyclic compounds could be made in the future.

The bioaccumulation of azaarenes has been studied by Southworth and others (Southworth, Beauchamp and Schmeider 1978; Southworth, Parkhurst and Beauchamp 1979; Southworth, Keffer and Beauchamp 1980). Compounds investigated included isoquinoline, acridine, benz[a]acridine, and dibenz[a,h]acridine. In experiments with fathead minnows, the bioaccumulation of isoquinoline and acridine agreed well with predicted values. However, benz[a]acridine and dibenz[a,h] acridine were bioconcentrated one and two orders of magnitude less than predicted. The deviation was shown to be caused by rapid metabolic degradation within the fish. Bioconcentration observed in Daphnia pulex increased with increasing Kows, as expected, unlike that observed for fathead minnows. The Kow values are predictors of bioaccumulation potential, but actual bioaccumulation may be species dependent. This phenomenon is addressed in the model by the use of the metabolic compartment. Unfortunately, no data are available on metabolic rate constants. There is no method to predict the metabolic degradation of chemicals within the fish. Metabolic degradation must be determined experimentally for compounds and aquatic species of interest. Data on the metabolism of compounds are expected to be available from our future investigations and can be incorporated into the model. 


\subsection{CONCLUSIONS AND RECOMMENDATIONS}

Application of APM to simulate coal liquid spills indicates that biodegradation is the predominant mechanism of removal for simple phenolics such as phenol and cresols from water. Because biodegradation is indicated as such an important removal mechanism of simple phenolics, better data should be obtained to confirm this and to determine the effects of biodegradation on the more complex compounds of this class.

\subsection{AQUATIC MODEL}

Aquatic modeling of organic pollutants is important because surface waters are easily reached by water-soluble components of waste or spilled pollutants. Our modeling efforts to date have resulted in a screening-level aquatic model. validation of this model is of primary importance to confirm or improve its capacity as a predictive tool. Further refinement of the model will give more definitive results as a better understanding of the behavior of coal liquid components is developed. Additional effort should be devoted to defining data and submodels needed to improve the aquatic model. Such improvements may include adapting the method used to solve the system of equations to permit the use of non-linear rate expressions. Communication between the experimental researchers and the inodeling team is essential to derive the greatest benefit from both the research and modeling efforts.

The current version of the aquatic pathways program considers only acute releases. A simple modification would allow chronic releases to be simulated.

Chemical of limited solubility could be modeled by adding a compartment of undissolved oil, which would make the source term more realistic. Data on successive extractions could be used in the development of this capability. Additional improvements may include refining the method for predicting the transfer rate of chemicals into and out of sediments, and the temperature dependence of biotic rate constants. 


\subsection{DATA BASE DEVELOPMENT}

The value of a computer program is dependent on availability of supporting data files. A data base was created for the aquatic pathways computer program. More effort should be devoted to expanding this data base to include information on additional compounds and parameters. This would involve a review of currently available data bases (such as EPA's CHEMFATE data base) and a review of parameters of potential interest such as $\mathrm{pKa}$ and $\mathrm{pH}$ dependence of reaction rates. Expanding the data base in this manner would ensure development of a generally useful data base.

Some properties of naphthols, indanols, and highly substituted phenols were not available in the literature and, therefore, were not used in the current version of the data base. Better estimates of the chemical properties of these compounds would make the results of the simulations more meaningful. In a survey of heterocyclic compounds, some data on properties and uptake were available. The use of a computerized data base would be the most time- and cost-effective means of expanding the data base of the APM to include more classes of chemicals. It would help to determine the availability of additional chemical data required, either from the literature or to be determined experimentally.

\subsection{UNCERTAINTY ANALYSIS}

Reporting the uncertainty in calculated results is necessary for the result to be of value. A method should be developed to estimate the uncertainty in the models and the parameter values used. Methods available in the literature should be reviewed and incorporated into our calculational capabilities. Included in this effort would be determination of statistical information on parameters in the chemical data base. At a minimum, a parameter indicating the quality of each value tabulated in the data base could be added. This would give the user some feeling for the uncertainties involved in the computations. 


\subsection{TERRESTRIAL MODEL}

The capability to model organic pollutants in the terrestrial environment should be developed. This could be done by modifying an existing program such as BIOTRAN (Gallegos, Garcia and Sutton 1980) or CREAMS (Knisel 1980) to describe pollutants of interest. This could require significant effort, and it would be helpful to involve terrestrial ecologists in the effort. This effort must be performed in conjunction with a data and submodel search for the particular pollutants of interest.

\subsection{RESEARCH NEEDS}

The literature search and results of the simulations indicate that further research should emphasize higher molecular weight phenolics and their persistence in the environment. The most persistent species such as C4-phenols, C5phenols, and indanols have the least-known characteristics. These are the only compounds investigated with octanol-water partition coefficients (Kow) greater than 1000, which indicates they would be the most important accumulators of this class. Biodegradation of these compounds, which may be an important loss mechanism, should be investigated. Biodegradation rates that were estimated for use in APM should also be confirmed experimentally. Biodegradation experiments using bacterial populations from a body of water which could be the receiver of a coal liquid spill are important for determining actual consequences from such an event.

Measurement of intake and depuration rates of compounds by fish and other biota is necessary to verify or modify the model. Measurement of metabolism of the compounds is needed to enhance the usefulness of the model for exposure estimation. Experimental data on uptake and release rates by sediments are also needed to modify the methods for estimating these processes. 


\subsection{REFERENCES}

Barte11, S. M., P. F. Landrum, J. P. Giesy and G. J. Leversee. 1981. "Simulated Transport of Polycyclic Aromatic Hydrocarbons in Artificial Streams." In Energy and Ecological Modeling, eds. W. J. Mitsch, R. W. Boserman, and J. M. Klopatek, pp. 133-143. Elsevier, New York.

Blau, G. E., W. B. Neely and D. R. Branson. 1975. "Ecokinetics: A Study of the Fate and Distribution of Chemicals in Laboratory Ecosystms." AICHE Journal 21(5):854-861.

Borighem, G., and J. Vereecken. 1978. "Study of the Biodegradation of Phenol in River Water." Ecol. Model. 4:51-59.

Briggs, G. G. 1973. "A Simple Relationship Between Soil Adsorption and Organic Chemicals and Their Octanol/Water Partition Coefficients." In Proceedings of the 7th British Insecticide and Fungicide Conference, pp. 83-86. British Crop Protection Council, London.

Brown, D. S., and E.W. Flagg. 1981. "Empirical Prediction of Organic Pollutant Sorption in Natural Sediments." EPA-600/J-80-026, J. Environ. Qual. $10(3): 382-386$.

Buikema, A. L., M. J. McGinniss and J. Cairns, Jr. 1979. "Phenolics in Aquatic Ecosystems: A Selected Review of the Recent Literature." Mar. Environ. Res. 2:87-181.

Burns, L. A., D. M. Cline and R. R. Lassiter. 1982. Exposure Analysis Modeling System (EXAMS): User Manual and System Documentation. EPA-600/3-82-023. Environmental Research Laboratory, U.S. Environmental Protection Agency, Athens, Georgia.

Call, D. J., L. T. Brooke and P. Y. Lu. 1980. "Uptake, Elimination, and Metabolism of Three Phenols by Fathead Minnows." Arch. Environ. Contam. Toxicol. 9:699-714.

Chambers, C. W., H. H. Tabak and P. W. Kabler. 1963. "Degradation of Aromatic Compounds by Phenol-Adapted Bacteria." J. Water Pollut. Control. Fed. $35(12): 1517-1528$.

Chapman, P. J. 1972. "An Outline of Reaction Sequences Used for the Bacterial Degradation of Phenolic Compounds." In Degradation of Synthetic Organic Molecules in the Biosphere, pp. 17-55. National Academy of Science, Washington, D. C.

Chiou, C. T., V. H. Freed, D. W. Schmedding and R. L. Kohnert. 1977. "Partition Coefficient and Bioaccumulation of Selected Organic Chemicals." Environ. Sci. and Technol. 11:475-478. 
Crosby, D. G. 1972. "Environmental Photooxidation of Pesticides." In Degradation of Synthetic Organic Molecules in the Biosphere, pp. 260-278. National Academy of Science, Washington, D.C.

DiToro, D. M., D. J. O'Connor, R. V. Thomann and J. P. St. John. 1981. "Simplified Model of the Fate of Partitioning Chemicals in Lakes and Streams." Paper presented at the workshop: Modeling the Fate of Chemicals in Aquatic Environment, August 17-21, 1981, Detroit, Michigan.

Dooley, J. E., S. E. Scheppelle, G. W. Sturm, P. W. Woodward and J. W. Vogh. 1978. "Comparative Composition of Petroleum and Synthetic Crude 0ils." In Synthetic Fossil Fuel Technology: Potential Health and Environmental Effects, eds. K. E. Cowser and C. R. Richmond, pp. 95-101. Ann Arbor Science Publishers, Inc., Ann Arbor, Michigan.

Gallegos, A. F., B. J. Garcia and C. M. Sutton. 1980. Documentation of TRU Biological Transport Model (BIOTRAN). LA-8313-MS Informal Report. Los Alamos Scientific Laboratory, Los ATamos, New Mexico. (a)

Gibson, D. T. 1972. "Initial Reactions in the Degradation of Aromatic Hydrocarbons." In Degradation of Synthetic Organic Molecules in the Biosphere, pp. 116-136. National Academy of Science, Washington, D.C.

Gi11, S. 1951. "A Process for the Step-by-Step Integration of Differential Equations in an Automatic Digital Computing Machine." Proc. Cambridge Philos. Soc. 47:96-108.

Hamelink, J. L., and A. Spacie. 1977. "Fish and Chemicals: The Process of Accumulation." Ann. Rev. Pharmocol. Toxicol. 17:167-177.

Hassett, J. J., J. C. Means, W. L. Banwart and S. G. Wood. 1980. Sorption Properties of Sediments and Energy-Related Pollutants. EPA 600/3-80-041. Environmental Research Lab/0ffice of Research and Development, U.S. Environmental Protection Agency, Athens, Georgia.

Helton, J. C., and P. C. Kaestner. 1981. Risk Methodology for Geologic Disposal of Radioactive Waste: Model Description and User Manual for Pathways Model. NUREG/CR-1636, Vol. 1 (SAND78-1711) U.S. Nuclear Regulatory Commission, Washington, D.C.

Hicks, R. E. 1981. "Mathematical Modeling: A BASIC Program to Simulate RealWorld Systems." In BYTE, pp. 72-86, June 1981. BYTE Publications, Inc.

Karickhoff, S. W., D. S. Brown and T. A. Scott. 1979. "Sorption of Hydrophobic Pollutants on Natural Sediments." Water Res. 13:241-248.

(a) Available for purchase from the National Technical Information Service, Springfield, VA 22161. 
Kenega, E. E., and C. A. I. Goring. 1980. "Relationship Between Water Solubility, Soil Sorption, Octanol-Water Partitioning, and Concentration of Chemicals in Biota." In Aquatic Toxicology, ASTM STP 707, eds. J. G. Eaton, P. R. Parrish and A. C. Hendricks, pp. 78-115. American Society for Testing and Materials, Philadelphia, Pennsylvania.

Knisel, W. G., ed. 1980. CREAMS: A Field-Scale Model for Chemicals, Runoff, and Erosion from Agricultural Management Systems. Conservation Research Report \#26, U.S. Department of Agriculture, Washington, D.C.

Kobayashi, K., and H. Akitake. 1975. "Studies on the Metabolism of Chlorophenols in Fish--IV Absorption and Excretion of Phenol in Goldfish." J. Agr. Food Chem. 18(1):92-96.

Lamberton, J. G., and R. R. Claeys. 1970. "Degradation of 1-Naphthol in Sea Water." J. Agr. Food Chem. 18(1):92-96.

Lang, D. L., ed. 1961. Absorption Spectra in the Ultraviolet and Visible Region, Vol. II. Academic Press, Inc. Publishers, New York.

Leo, A., C. Hansch and D. Elkins. 1971. "Partition Coefficients and Their Uses." Chemical Reviews 71(6):525-616.

Lu, Po-Yung, and R. L. Metcalf. 1975. "Environmental Fate and Biodegradability of Benzene Derivatives as Studied in a Model Aquatic Ecosystem." Environ. Health Persp. 10:269-284.

Mackay, D., and S. Paterson. 1981. "Calculating Fugacity." Environ. Sci. Technol. 15(9):1006-1014.

Metcalf, R. L., F. K. Sangha and I. P. Kapoor. 1971. "Model Ecosystem for the Evaluation of Pesticide Biodegradability and Ecological Magnification." Environ. Sci. Technol. 5:709.

Napier, B. A., W. E. Kennedy, Jr. and J. K. Soldat. 1981. PABLM: A Computer Program to Calculate Accumulated Radiaton Doses from Radionuclides in the Environment (a) PNL-3209, Pacific Northwest Laboratory, Richland, Washington. (a)

Neely, W. B. 1979a. "A Preliminary Assessinent of the Environmental Exposure to be Expected from the Addition of a Chemical to a Simulated Aquatic Ecosystem." Intern. J. Environ. Studies. 13:101-108. Gordon and Breach Science Publishers, Ltd., Great Britain.

Neely, W. B. 1979b. "Estimating Rate Constants for the Uptake and Clearance of Chemicals by Fish." Environ. Sci. and Technol. 13(12):1506-1510.

(a) Available for purchase from the National Technical Information Service, Springfield, VA 22161. 
Neely, W. B., and G. E. Blau. 1977. "The Use of Laboratory Data to Predict the Distribution of Chlorpyrifos in a Fish Pond." Pesticides in Aquatic Environments, pp. 145-163. Plenum Press, New York.

Neely, W. B., D. R. Branson and G. E. Blau. 1974. "Partition Coefficient to Measure Bioconcentration Potential of Organic Chemicals in Fish." Environ. Sci. Technol. 8:1113-1115.

Niemczyk, S. J. 1980. A Model for Radioactive Transport in the Aquatic Ecosystem. NUREG/CR-1597 (SAND80-1670). U.S. Nuclear Regulatory Commission, Washington, D.C. (a)

Norstrom, R. J. A. E. McKinnon and S. W. DeFreitas. 1976. "A BioenergeticsBased Model for Pollutant Accumulation by Fish Simulation of PCB and Methylmecury Residue Levels in Ottawa River Yellow Perch (Perca Flavescens). J. Fish. Res. Board Can. 33:248-267.

Onishi, Y., and D. S. Trent. 1981. Mathematical Simulation of Sediment and Radionuclide Transport in Surface waters. NUREG/CR-1034 (PNL-3120), U.S. Nuclear Regulatory Commission, Washington, D.C. (a)

Petty, S. E., W. Wakamiya, C. J. English, J. A. Strand and D. D. Mahlum. 1982. Assessment of Synfuel Spi11 Cleanup Options. PNL-4244, Pacific Northwest Laboratory Richland, Washington.

PNL. 1982. Pacific Northwest Laboratory Annual Report for 1981 to the DOE Office of Energy Research, Part 2 - Ecological Sciences. PNL-4100, PT2, Pacific Northwest Laboratory, Richland, Washington.

Smith, J. H., W. R. Mabey, N. Bohonos, B. R. Holt, S. S. Lee, T. W. Chou, D. C. Bomberger and T. Mi11. 1977. Environmental Pathways of Selected Chemicals in Freshwater Systems, Part I: Background and Experimental Procedures. EPA-600/7-77-713, Environmental Protection Agency, Washington, D.C.

Smith, J. H., W. R. Mabey, N. Bohonos, B. R. Holt, S. S. Lee, T. W. Chou, D. C. Bomberger and T. Mi11. 1978. Environmental Pathways of Selected Chemicals in Freshwater Systems, Part II: Laboratory Studies. EPA-600/7/78-074, Environmental Protection Agency, Washington, D.C.

Southworth, B. R., J. J. Beauchamp and P. K. Schmeider. 1978. "Bioaccumulation Potential and Acute Toxicity of Synthetic Fuels Effluents in Freshwaer Biota: Azaarenes." Env. Sci. Technol. 12(9):1062-1066.

Southworth, G. R., B. R. Parkhurst and J. J. Beauchamp. 1979. "Accumulation of Acridine from Water, Food, and Sediment by the Fathead Minnow, Pimephales promelas." Water, Air, Soil Pollut. 12(3):331-342.

(a) Available for purchase from the National Technical Information Service, Springfield, VA 22161. 
Southworth, G. R., C. C. Keffer and J. J. Beauchamp. 1980. "Potential and Realized Bioconcentration - A Comparison of Observed and Predicted Bioconcentration of Azaarenes in the Fathead Minnow." Env. Sci. Technol. 14(12).

Stolbunov, A. K. 1976. "Microbial Decomposition of Phenols in the Volga and its Reservoirs." Hydrobiological J. 12(1):24-29.

Strand, J. A., III, and B. E. Vaughan, eds. 1981. Ecological Fate and Effects of Solvent Refined Coal (SRC) Material: A Status Report. PNL-3819, Pacific Northwest Laboratory, Richland, Washington. (a)

Swift, D. J. 1978. "Some Effects of Exposing Rainbow Trout (Salmo Gairdneri Richardson) to Phenol Solutions." J. Fish. Biol. 13(7).

USNRC. 1977. Calculation of Annual Doses to Man from Routine Releases of Reactor Effluents for the Purpose of Evaluating Compliance with 10 CFR Part 50, Appendix I. Regulatory Guide 1.109, Rev. 1, U.S. Nuclear Regulatory Commission, Washington, D.C.

U.S. Department of Transportation. 1982. Polluting Incidents in an Around U.S. Waters, Calendar Year 1980 and 1981. COMDTINST M16450.2D. United States Coast Guards, Washington, D.C.

Veith, G. D., D. L. Defoe and B. V. Bergstedt. 1979. "Measuring and Estimating the Bioconcentration Factor of Chemicals in Fish." J. Fish. Res. Bd. Can. 36:1040-1048.

Veith, G. D., K. J. Macek, S. R. Petrocelli and J. Carroll. 1980. "An Evaluation of Using Partition Coefficients and Water Solubility to Estimate Bioconcentrtion Factors for Organic Chemicals in Fish." In Aquatic Toxicology, ASTM STP 707:116-129, eds. J. G. Eaton, P. R. Parrish and A. C. Hendricks, American Society for Testing and Materials, Phildelphia, Pennsylvania.

Wilson, B. W., R. Pelroy and J. T. Cresto. 1980. "Identification of Primary Aromatic Amines in Mutagenically Active Subfractions from Coal Liquefaction Materials." Mutation Res. 79:193-202.

Wolfe, N. L., R. G. Zepp, G. L. Baughman, R. C. Fincher and J. A. Gordon. 1976. Chemical and Photochemical Transformation of Selected Pesticides in Aquatic Systems. EPA-600/3-76-067. U.S. EPA Office of Research and Deve1opment, Environmental Research Lab., Athens, Georgia.

Zepp, R. G., and D. M. Cline. 1977. "Rates of Direct Photolys is in the Aquatic Environment." Environ. Sci. Technol. 11(4):359-365.

(a) Available for purchase from the National Technical Information Service, Springfield, VA 22616. 
. 
OFFSITE

- DOE Technical Information Center (27)

E. L. Alpen

Lawrence Berkeley Laboratory

University of California

Building 90, Room 2056

No. 1 Cyclotron Road

Berkeley, CA 94720

L. D. Attaway

1005 A Steet

Suite 405

San Rafael, CA 94901

- N. F. Barr

ER-73, GTN

U.S. Department of Energy

Washington, DC 20545

J. Batchelor

FE-43, GTN

U.S. Department of Energy

Washington, DC 20545

D. L. Bauer, Acting Assistant

Secretary for Fossil Energy

FE-1, FORSTL

U.S. Department of Energy

Washington, DC 20585

H. L. Bergman

University of Wyoming

Laramie, WY 82071

C. Berlin

Health Environmental Review Division U.S. Environmental Protection Agency Washington, DC 20460

R. W. Biles

Exxon Corporation

Research and Environmental Health Division

Medical Department

P. 0. Box 235

East Millstone, NJ 08873

- Recipient of PNL-4202, App. A-D (bound separately).
J. R. Blair

ER-73, GTN

U.S. Department of Energy

Washington, DC 20545

V. P. Bond

Brookhaven National Laboratory

Upton, Long Island, NY 11973

R. G. Boykin

Catalytic, Inc.

P. 0. Drawer 239

Wilsonville, AL 35186

J. E. Bratina, Jr.

Environmental Research and

Technology, Inc.

601 Grant Street

Porter Building, 10th Floor

Pittsburgh, PA 15219

A. Brink

SASOL Technology (Proprietary), Ltd.

57 Commissioner Street

P. 0. Box 5486

Johannesburg 2000

REPUBLIC OF SOUTH AFRICA

P. E. Brubaker

Exxon Corporation

Research and Environmental Health

Division

Medical Department

P. 0. Box 235

East Millstone, NJ 08873

- P. Buh1

FE-43, GTN

U.S. Department of Energy

Washington, DC 20545

H. H. Bulkowski

Catalytic, Inc.

Centre Square West

1500 Market Street

Philadelphia, PA 19102

F. P. Burke

Conoco Coal Development Co.

4000 Brownsville Road

Library, PA 15129 
J. A. Carroll, Capt., USA

Medical Bioengineering R\&D Laboratory

Ft. Detrick, MD 21701

C. E. Carter, Scientific Director National Institute of Environmental Health Sciences

P. 0. Box 12233

Research Triangle Park, NC 27709

M. Chartock

Science \& Public Policy Program

Norman, OK 73019

C. T. Chen

OSHA

U.S. Department of Labor

200 Constitution Avenue, Nw

Washington, DC 20210

- P. Cho

ER-73, GTN

U.S. Department of Energy

Washington, DC 20545

A. V. Colucci

A. V. Colucci \& Associates, Inc. 15305 Calle Enrique, Suite D

Morgan Hill, CA 95037

- K. E. Cowser (4)

Oak Ridge National Laboratory

P. 0. Box $X$

Oak Ridge, TN 37830

G. Day

Kentucky Division of Air Pollution Control

18 Riley Road

Frankfort, KY 40601

Department of Library and

Archives (2)

James Nelson, Librarian

Box 537, Berry Hill

Frankfort, KY 40602

DOE Public Document Room (2)

Attn: Mr. R. A. Evans

Room G-298, Federal Building

P. 0. Box $E$

Oak Ridge, TN 37830
DOE Public Reading Room, FOI (2)

Room IE-180, Forrestal Bldg.

1000 Independence Avenue, SW

Washington, DC 20585

DOE Technical Information Center (2)

Customer Services Branch

P. 0. Box 62

Oak Ridge, TN 37830

D0E Public Document Room (2)

Room G208

Oak Ridge Federal Building

Oak Ridge, TN 37830

DOE Public Reading Room (2)

Room GA- 142

Forrestal Building

1000 Independence Avenue, SW

Washington, DC 20585

B. Z. Drozdowicz

International Coal Refining Co.

P. 0. Box 2752

Allentown, PA 18001

C. Drummond

Pittsburgh Energy Technology Center

P. 0. Box 10940

Pittsburgh, PA 15236

- A. P. Duhamel (25)

ER-74, GTN

U.S. Department of Energy

Washington, DC 20545

H. E. Dunn

Indiana State University, Evansville 8600 University Boulevard

Evansville, IN 47702

M. J. Eaman

Concord Scientific Corporation

3101-B Hawthorn Road

Ottawa, Ontario, K1G-3H9

CANADA

C. W. Edington, Associate Director

Office of Health and Environmental

Research

ER-70, GTN

U.S. Department of Energy

Washington, DC 20545 
H. Enoch

Kentucky Department of Energy

P. 0. Box 11888

Lexington, KY 40578

J. L. Epler

Oak Ridge National Laboratory

P. 0. Box $X$

Oak Ridge, TN 37830

Evansville \& Vanderburgh County

Public Library (2)

Attn: Ann Pearson

22 Southeast 5 th Street

Evansville, IN 47708

J. P. Fillo

Environmental Research and

Technology, Inc.

601 Grant Street

Porter Building, 10th Floor

Pittsburgh, PA 15219

C. H. Fisher

FE-43, GTN

U.S. Department of Energy

Washington, DC 20545

S. Foster

Energy and Environmental Analysis, Inc.

1111 North 19th Street

Arlington, VA 22209

L. Fradkin

Argonne National Laboratory

Building 12

Argonne, IL 60439

R. E. Franklin

ER-75, GTN

U.S. Department of Energy

Washington, DC 20545

R. J. Fry

Oak Ridge National Laboratory

P. 0. Box $X$

Oak Ridge, TN 37830

K. Frye

FE-40, GTN

U.S. Department of Energy

Washington, DC 20545
A. A. Galli

U.S. Environmental Protection Agency

401 M Street, SW

Washington, DC 20460

C. W. Gehrs

Oak Ridge National Laboratory

P. 0. Box $X$

Oak Ridge, TN 37830

H. Gerstenkorn

Ruhrkohle Oel und Gas GMBH

Gleiwitzer Platz 3

4250 Bottropp

FEDERAL REPUBLIC OF GERMANY

J. M. Giddings

Oak Ridge National Laboratory

P. 0. Box $X$

Oak Ridge, TN 37830

G. F. Goethe 1

VEBA OEL AG

Postfach 45

4660 Gelsenkirchen-Buer

FEDERAL REPUBLIC OF GERMANY

L. Goldberg

Chemical Industrial Institute of

Toxicology

2109 Nancy Ann Drive

Raleigh, NC 27607

G. Goldstein

ER-74, GTN

U.S. Department of Energy

Washington, DC 20545

J. Gray

Ashland Synthetic Fuels, Inc.

P. 0. Box 391

Ashland, KY 41101

M. D. Gray

NCB (Coal Products), Ltd.

Coal House, Lyon Road

Harrow, HAI 2EX

ENGLAND

A. R. Griesemer

Oak Ridge National Laboratory

P. 0. Box $X$

Oak Ridge, TN 37830 
M. Guerin

Oak Ridge National Laboratory

P. 0. Box X

Oak Ridge, TN 37830

R. M. Hamilton

FE-43, GTN

U.S. Department of Energy

Washington, DC 20545

A. Hartstein

FE-43, GTN

U.S. Department of Energy

Washington, DC 20545

L. Headley

Morgantown Energy Technology Center

Morgantown, WV 26505

G. E. Hedstrom

FE-44, GTN

U.S. Department of Energy

Washington, DC 20545

M. G. Henry

Columbia National Fisheries

Research Laboratory

Route 1

Columbia, MO 65201

B. Henschel (2)

Industrial Environmental Research

Laboratory

MD-61, U.S. EPA

Research Triangle Park, NC 27711

J. Hill

Ashland Synthetic Fuels, Inc.

P. 0. Box 391

Ashland, KY 41101

R. $\mathrm{Hi} 11$

Ashland Synthetic Fuels, Inc.

P. 0. Box 391

Ashland, KY 41101

C. H. Hobbs

Lovelace Inhalation Toxicology

Research Institute

P. 0. Box 5890

A1buquerque, NM 87115
H. L. Hollister, Assistant Secretary

Environmental Protection, Safety

and Emergency Preparedness

EP-1, FORSTL

U.S. Department of Energy

Washington, DC 20585

G. R. Holt

ARCO Coal Company

1860 North Lincoln Street

P. 0. Box 5300

Denver, CO 80217

H. Hosang

VEBA OEL AG

Postfach 45

4660 Gelsenkirchen-Buer

FEDERAL REPUBLIC OF GERMANY

P. House

EP-33, FORSTL

U.S. Department of Energy

Washington, DC 20585

W. Hubis

4031 South Magnolia Way

Denver, C0 80237

E. L. Huffman

Southern Company Services, Inc.

P. 0. Box 2625

Birmingham, AL 35202

S. Ikeda

Japan Coal Liquefaction Development Co. , Ltd.

Rm. 1115, Shuwa Kioj-Cho TBR Bldg.

No. 7, Kojimachi 5-chome,

Chiyoda-Ku, Tokyo 102

JAPAN

H. Inhaber

Oak Ridge National Laboratory

P. 0. Box $X$

Oak Ridge, TN 37830 
J. C. Johnson

FE-13, GTN

U.S. Department of Energy

Washington, DC 20545

T. W. Johnson

Southern Company Services, Inc.

$\%$ Catalytic, Inc.

P. 0. Drawer 239

Wilsonville, AL 35186

W. S. Jones

FE-43, GTN

U.S. Department of Energy

Washington, DC 20545

L. Joseph

Hydrocarbon Research, Inc.

1313 Dolly Madison Blvd.

McLean, VA 22101

J. S. Kane, Deputy Director

Office of Energy Research

ER-2, FORSTL

U.S. Department of Energy

Washington, DC 20585

- C. M. Kelly

International Coal Refining Co.

P. 0. Box 2752

Allentown, PA 18001

D. L. Kloepper

The Pittsburg \& Midway Coal Mining Company

P. 0. Box 3396

Denver, C0 80155

H. E. Lewis

Catalytic, Inc.

P. 0. Box 239

Wilsonville, AL 35186

S. C. Lewis

Exxon Corporation

Research and Environmental

Health Division

Medical Department

P. 0. Box 235

East Millstone, NJ 08873
R. R. Maddocks

Catalytic, Inc.

Centre Square West

1500 Market Street

Philadelphia, PA 19102

M. J. Massey (2)

Environmental Research and

Technology, Inc.

601 Grant Street

Porter Building, 10th Floor

Pittsburgh, PA 15219

H. McCammon

ER-75, GTN

U.S. Department of Energy

Washington, DC 20545

R. 0. McClellan

Lovelace Inhalation Toxicology

Research Institute

P. 0. Box 5890

Albuquerque, NM 87115

G. V. McGur 1

Pittsburgh Energy Technology Center

P. 0. Box 10940

Pittsburgh, PA 15236

R. E. McKee

Exxon Corp.

Research and Environmental

Health Division

Medical Department

P. 0. Box 235

East Millstone, NJ 08873

P. M. Mehrle

Columbia National Fisheries

Research Laboratory

Route 1

Columbia, MO 65201

M. L. Mendelsohn

Lawrence Livermore Laboratory

University of California

P. 0. Box 808

Livermore, CA 94550

L. Miller (2)

FE-42, GTN

U.S. Department of Energy

Washington, DC 20545 
M. L. Minthorn

ER-72, GTN

U.S. Department of Energy

Washington, DC 20545

A. Moghissi

U.S. Environmental Protection Agency

401 M Street, SW

Washington, DC 20460

N. B. Munro

Fossil Energy Information Center Building 9207

0ak Ridge National Laboratory

P. 0. Box $Y$

Oak Ridge, TN 37830

Morgantown Public Library (2)

373 Spruce Street

Morgantown, WV 26505

E. C. Moroni

FE-43, GTN

U.S. Department of Energy

Washington, DC 20545

S. C. Morris

Brookhaven National Laboratory

Building 475

Upton, NY 11973

P. J. Musser

FE-44, GTN

U.S. Department of Energy

Washington, DC 20545

M. B. Neuworth

The Mitre Corp.

1820 Dolly Madison Blvd.

McLean, VA 22102

J. Norwood

International Coal Refining Co.

P. 0. Box 2752

Allentown, PA 18001

Owensboro-Davies County

Public Library (2)

Attn: Alice G. Lewis

450 Griffith Avenue

Owensboro, KY 42301
B. Pallay

National Institute for 0ccupational

Safety \& Health

5600 Fishers Lane

Rockville, MD 20852

M. Parmenter

Kerr-McGee Corporation

Kerr-McGee Center

Packaging \& Labeling Dept.

Oklahoma City, OK 73125

R. M. Perhac

Electric Power Research Institute

P. 0. Box 10412

Palo Alto, CA 93404

W. Piver

National Institute of Environmental

Health Sciences

P. 0. Box 12233

Research Triangle Park, NC 27709

J. D. Potts

Cities Service Research \&

Development Co.

Box 3908

Tulsa, OK 74102

J. Reafsnyder (2)

Oak Ridge Operations

U.S. Department of Energy

P. 0. Box E

Oak Ridge, TN 37830

C. Reaux

National Institute for Occupational Safety \& Health

Room 117

944 Chestnut Ridge Road

Morgantown, WV 26504

C. A. Reilly

Argonne National Laboratory

9700 South Cass Avenue

Argonne, IL 60439

H. Retcossky

Pittsburgh Energy Technology Center

P. 0. Box 10940

Pittsburgh, PA 15236 
D. E. Rhodes

Kerr-McGee Corporation

P. 0. Box 035

Crescent, OK 73028

W. J. Rhodes (2)

Industrial Environmental

Research Laboratory

MD-61, US EPA

Research Triangle Park, NC 27711

C. R. Richmond

Oak Ridge National Laboratory

P. 0. Box $X$

0ak Ridge, TN 37830

R. Roland

Argonne National Laboratory

9700 South Cass Avenue

Argonne, IL 60439

T. C. Ruppe 1

Pittsburgh Energy Technology Center

P. 0. Box 10940

Pittsburgh, PA 15236

- H. D. Schindler

The Lummus Company

1515 Broad Street

Bloomfield, NJ 07003

-D. K. Schmalzer

The Pittsburg \& Midway Coal

Mining Co.

P. 0. Box 3396

Denver, CO 80155

M. Schulman

ER-70, GTN

U.S. Department of Energy

Washington, DC 20545

0. J. Schwarz

Botany Department

University of Tennessee

Knoxville, TN 37916

R. Scripsick

P. 0. Box 1663, MS-986

Los Alamos, NM 87545
A. G. Sharkey

Pittsburgh Energy Technology Center

P. 0. Box 10940

Pittsburgh, PA 15236

A. Shepard

American Petroleum Institute

2101 L Street, NW

Washington, DC 20037

C. Shih

TRW

1 Space Park

R42142

Redondo Beach, CA 90278

D. A. Smith

ER-72, GTN

U.S. Department of Energy

Washington, DC 20545

V. G. Stamoudis

Argonne National Laboratory

9700 South Cass Avenue

Argonne, IL 60439

- G. E. Stapleton

ER-72, GTN

U.S. Department of Energy

Washington, DC 20545

J. Stasior

Enviro Control

11300 Rockville Pike

Rockville, MD 20852

R. J. Stern

EP-33, FORSTL

U.S. Department of Energy

Washington, DC 20585

J. Stetter

Argonne National Laboratory 9700 South Cass Avenue

Argonne, IL 60439

J. A. Strasser

Atlantic Coal Institute

P. 0. Box 1133

Sydney, Nova Scotia

CANADA BIP 6J7 
J. Talty

National Institute for Occupational Safety \& Health

5600 Fishers Lane

Rockville, MD 20852

J. Tao

International Coal Refining Co.

P. 0. Box 2752

Allentown, PA 18001

J. W. Thiessen, Deputy Associate Director

Office of Health and Environmental Research

ER-71, GTN

U.S. Department of Energy

Washington, DC 20545

G. G. Thurlow

National Coal Board

Coal Research Establishment

Stoke Orchard

Cheltenham, Glos. GL52 4RZ

ENGLAND

R. V. Trense

Exxon Corporation

Environmental Affairs Programs

Exxon Research \& Engineering Co.

P. 0. Box 101

Florham Park, NJ 07932

A. W. Trivelpiece, Director (3)

Office of Energy Research

ER-1, FORSTL

U.S. Department of Energy

Washington, DC 20585

University of Kentucky (2)

Attn: J. Pivarnik

Government Publications Department

M. L. King Library

Lexington, KY 40506

- G. K. Vick (2)

Exxon Corporation

P. 0. Box 101

Florham Park, NJ 07932
G. L. Voelz

University of California

Los Alamos Scientific Laboratory

P. 0. Box 1663

Los Alamos, NM 97545

W. H. Weber

EPRI

\% catalytic, Inc.

P. 0. Drawer 239

Wilsonville, AL 35186

Library (2)

West Virginia University

Downtown Campus

Attn: C. Hamerick

Morgantown, WV 26505

K. Wilzbach (4)

Argonne National Laboratory

9800 South Cass Avenue

Argonne, IL 60439

F. E. Witmer

EP-33, GTN

U.S. Department of Energy

Washington, DC 20545

- F. J. Wobber (10)

ER-75, GTN

U.S. Department of Energy

Washington, DC 20545

R. W. Wood

ER-74, GTN

U.S. Department of Energy

Washington, DC 20545

\section{ONSITE}

DOE Richland Operations Office

H. E. Ransom

Pacific Northwest Laboratory (110)

- R. L. Aaberg (10)

L. E. Anderson

W. J. Bair

R. M. Bean

C. D. Becker

F. G. Burton

W. C. Cannon

D. A. Cataldo 
Pacific Northwest Laboratory (contd)

E. K. Chess

J. F. Cline

D. D. Dauble

H. Drucker

W. E. Fallon

L. J. Felice

W. D. Felix

D. H. Fickeisen

M. E. Frazier

-R. H. Gray (30)

P. L. Hackett

D. R. Kal kwarf

M. T. Karagianes

B. J. Kelman

J. C. Kutt

D. W. Later

R. H. Lovely

D. D. Malhum

S. Marks

R. P. Marshall

P. J. Mellinger

J. E. Morris

0 . R. Moss

T. Nelson

J. M. Nielsen

C. M. Novich

D. E. Olesen

T. L. Page

-R. A. Peloquin

R. A. Pelroy

R. W. Perkins
R. D. Phillips

H. A. Ragan

R. A. Renne

R. E. Schirmer

R. P. Schneider

D. M. Schoengold

- R. G. Schreckhise

M. R. Sikov

S. D. Sklarew

L. G. Smith

D. L. Springer

D. L. Stewart

J. A. Strand

- D. L. Strenge

W. L. Templeton

T. A. Toste

D. Tolley

B. E. Vaughan

M. L. Warner

W. C. Weimer

R. E. Wildung

W. R. Wiley

D. H. Willard

B. W. Wilson

C. W. Wright

- Biology Publications Office

- Technical Information (5)

- Publishing Coordination (2) 
